\title{
Political environment and financial crises
}

\section{Thanh C. Nguyen 지 | Vítor Castro \ | Justine Wood}

School of Business and Economics, Loughborough University, Loughborough, UK

\section{Correspondence}

Thanh C. Nguyen, School of Business and Economics, Loughborough University, Epinal Way, Loughborough LE11 3TU, UK.

Email: t.c.nguyen@lboro.ac.uk

\begin{abstract}
This paper assesses the role of the political environment in the timing of financial crises over a sample of 85 countries during the period 1975-2017. We consider systemic banking, currency and sovereign debt crises in addition to twin and triple crises. Using a fixed-effects logit model, this study shows that banking and currency crises are more likely to occur within 1 year after elections. There is also evidence that the probability of currency crises increases when right-wing parties are in office. Moreover, time in office of incumbent chief executives reduces the likelihood of any type of financial crises. The incidence of twin and triple crises is lower when majority governments are in office. This study contributes to the literature by calling attention to the importance of some political factors for different types of financial crises.

\section{K E Y W O R D S}

economic uncertainty, financial crisis, political environment
\end{abstract}

\section{1 | INTRODUCTION}

Research on financial crises has evolved over time with studies on the 1930s Great Depression, the 1994 Tequilla crisis, the 1994-1995 Latin American crisis, the 1997-1998 East Asian crises, and more recently the 2007-2008 global financial crisis. As the world's largest economies are more deeply interconnected compared to the 1990s, financial crises can have domestic or external origins and can rapidly spread across borders with severe consequences. Policymakers have responded to financial crises in different ways and using different instruments, depending on the respective type, magnitude and consequences. Even though such interventions are carefully designed, they tend to be inefficient and costly for government budgets. In view of large costs and consequences associated with

[Corrections added on 25 August 2020, after first online publication: In the original-published article the given and family names of the third author was erroneously transposed. This version corrects the mistake.] financial crises, predicting them is undoubtedly a major concern for both academics and policymakers.

A substantial body of research has explored the immediate causes of financial crises by looking at credit expansions (Perugini, Holscher, \& Collie, 2016), a range of macroeconomic factors (Demirguc-Kunt \& Detragiache, 2005; Falcetti \& Tudela, 2006), institutional quality (De Bonis, Giustiniani, \& Gomel, 1999) or financial regulations (Barth, Caprio, \& Levine, 2004; Caprio Jr., D'Apice, Ferri, \& Puopolo, 2014; Kim, Koo, \& Park, 2013). However, the role of the political environment in the timing of financial crises remains largely unexplored. Among a few works that take political factors into account, the role of political stability has been the most prominent (see, e.g., Aisen \& Veiga, 2013; Shimpalee \& Breuer, 2006; Vaugirard, 2007). This paper aims at providing a more complete picture of the link between political environment and financial crises. For that purpose, we examine how the electoral cycle, political ideology, political stability and government support have influenced the likelihood of financial crises over the last four decades. 
Previous studies tend to focus on only one type of financial crisis (see, e.g., Demirguc-Kunt \& Detragiache, 1998; Vaugirard, 2007; Yu, 2016). However, crises have different specificities that make it possible to distinguish them into different types. Moreover, different types of financial crises tend to be related and come in waves (Laeven \& Valencia, 2020). Therefore, it is important to dig deeper into the effects of different political factors on different types of financial crises. Motivated by the works of Laeven and Valencia (2020) and Kim et al. (2013), three main types of financial crises are considered: systemic banking crises, currency crises and sovereign debt crises. Reinhart and Rogoff (2011), Kaminsky and Reinhart (1999) and Balteanu and Erce (2018) provide both the theoretical framework and empirical evidence of the linkages among them, leading to the so-called twin and triple crises. Another aim of this study is to distinguish the impact of the political environment on the likelihood of systemic banking, currency, debt and twin and triple crises. This analysis allows us to uncover the impact of political factors on the prevalence of different types of crises. This is an important contribution to the existing literature on the causes and timing of financial crises.

A fixed-effects logit model is employed to test the impact of the political factors on the likelihood of financial crises as a whole and their different types over a sample of 85 developed and developing countries during the period 1975-2017. This analysis provides some striking findings and helps to uncover the important, but overlooked, role of the political environment on the unfolding and timing of financial crises. In particular, this study shows that: (a) banking and currency crises are more likely to occur within the first year after elections; (b) the likelihood of currency crises increases with right-wing governments; (c) the probability of any type of financial crises is smaller when incumbent chief executives stay in office for longer; and (d) majority governments significantly reduce the probability of twin and triple crises.

One important conclusion of this paper is that the role of the political environment on the development of financial crises is better understood when the analysis focuses on the individual types of crises rather than treating them all as simply "financial crises."

The organization of this paper is as follows: Section 2 reviews the relevant literature. The methods to identify financial crises are discussed in Section 3. Section 4 describes the data and econometric methodology. The empirical findings are presented and discussed in Section 5. Section 6 concludes.

\section{2 | REVIEW OF THE LITERATURE}

The literature on the causes of financial crises focuses on the imbalances of a wide variety of economic factors that are often accompanied by worsening macroeconomic conditions. Kaminsky, Lizondo, and Reinhart (1998) use 95 economic variables to detect early warning signals of currency crises and find that international reserves, credit growth, domestic inflation, real GDP growth and fiscal deficits are useful for currency crisis anticipation. In the same vein, Demirguc-Kunt and Detragiache $(1998,2005)$ find that higher credit growth, interest and inflation rate and the presence of a deposit insurance scheme increase the likelihood of banking crises. Moreover, investing 50 economic factors in a large sample of countries, Manasse and Roubini (2009) report that sovereign debt crises are less likely to occur in countries with low levels of short-term debt to reserves and public external debt to fiscal revenue.

Despite government efforts, financial crises do occur and indicate the essence that they are unpredictable. If authorities could accurately predict financial crises, governments would have the ability to stop financial imbalances from growing to the points where they turn into financial crises. Even when policymakers can locate the exact causes of a financial crisis, macro-prudential policies tend to be inefficient because of their unpredictable counter-cyclical effects (Goodhart, 2011). This could explain why some countries like Argentina face repeated financial crises. ${ }^{1}$ It is difficult to explain the inefficient preventive policies and the recurrence of such undesirable events without considering the effects of political factors.

This study extends the existing literature on financial crises by considering the role of the political environment. This is an important dimension that has been overlooked by the literature. Political factors have long been studied as important conditionings in different areas. This paper aims at bringing this dimension to the study of financial crises and respective types.

There are reasons to consider that financial crises might be influenced by political factors. Political business cycles literature claims that governments act opportunistically before elections by inducing short-term economic expansions to increase their chances of re-election (Nordhaus, 1975; Rogoff, 1990; Rogoff \& Sibert, 1988); this excessive spending is compensated after elections by spending cuts and tax increases that end up cooling down economic growth. This means that after elections financial crises have better chances to proliferate. Pástor and Veronesi (2012) stress that elections also come with political uncertainty. Vaugirard (2007) argues that this uncertainty has been a catalyst for financial crises because market participants are uncertain about policy continuity. Various studies provide both theoretical arguments and empirical evidence of the adverse effects from electoral uncertainty, such as higher stock return volatility (Bialkowski, Gottschalk, \& Wisniewski, 2008), financing 
cost (Kelly, Pástor, \& Veronesi, 2016), equity price and bond yields (Snowberg, Wolfers, \& Zitzewitz, 2007), and lower corporate investments (Jens, 2017; Julio \& Yook, 2012; Yonce, 2015).

Another type of uncertainty is the uncertainty about the impact of policies implemented by newly elected governments (Burgoon, Demetriades, \& Underhill, 2012; Pástor \& Veronesi, 2012). Extensive reforms are usually implemented during an incumbent's first year in office, which increases macroeconomic uncertainty and the probability of financial crises (Abiad \& Mody, 2005). This is the so-called "honeymoon hypothesis." Alesina, Roubini, and Cohen (1997), Veiga and Veiga (2004) and Burgoon et al. (2012) confirm this hypothesis and report that new policies tend to be implemented in the immediate aftermath of elections, resulting in the higher risk of policy changes. The risk could be higher when a newly elected government has an opposite political ideology to the previous one. New governments may have more incentive to implement financial reforms to realize their benefits before the next election (Krueger, 1993, p. 124). However, it is not always clear whether proposed policy changes or reforms during honeymoon periods are motivated by partisan considerations or by purposes of social welfare (Abiad \& Mody, 2005; Pástor \& Veronesi, 2012). These findings lead us to conjecture that the probability of financial crises is higher within the first year after elections.

Political ideology can also play a role in the unfolding of financial crises. Governments are heterogeneous in the sense that they are characterized by the left-wing or right-wing governments' spectrum of their ideologies. Hence, they tend to be identified as having opposite economic policies (Alesina, 1987; Hibbs, 1977, 1987). While left-wing governments tend to favour higher government spending, stricter market and business regulations and stronger government interventions, right-wing governments are more prone to promote economic freedom, free trade and deregulation (Castro \& Martins, 2019), sustainable development (Aidt, Castro, \& Martins, 2018) and reduction in government spending (Pickering \& Rockey, 2011, 2013). These different behaviours may also influence the build-up and unfolding of financial crises.

Bechtel (2009) shows that there are three channels through which right-wing governments promote financial stability and reduce economic policy uncertainty. First, they tend to pursue friendly and reliable investment policies, which benefit high-income individuals and investors. They will try to secure a favourable investment environment by reducing economic policy uncertainty. Second, right-wing governments with favourable policies for the business environment tend to have strong connections with industrial associations and firms. This reduces the cost of information sharing and improves the confidence of market participants about future economic policies, leading to a better performance of the financial market and the reduction of systematic capital risk. Third, right-wing governments appear to have better reactions to exogenous economic shocks. Industrial associations and firms are the first to absorb the side effects of an economic policy (Brauninger \& Bernhagen, 2005). By having strong relationships with them, right-wing governments might be better informed about the negative sides of a policy and hence can react more efficiently to economic shocks. For these reasons, we hypothesize that financial crises might also be less likely during their tenures.

Political stability is another important aspect of the political environment to which some attention has been given by Vaugirard (2007), Shimpalee and Breuer (2006) and Aisen and Veiga (2013). The frequent changes in incumbent executives can undermine the overall stability and the efficiency of macro-prudential policies, which in turn might increase the probability of a financial crisis. Thus, a longer length of an incumbent executive, the more likely that he can continue his announced programmes and promote economic stability. This reduces the uncertainty regarding future policy changes, which has been proved to be detrimental to various economic and social activities (see, e.g., Aisen \& Veiga, 2013; Jens, 2017). Moreover, when governments are unable to pursue their announced programmes and to stay in office, international investors can respond to such political instability by withdrawing their investments on a large scale, which may result in a panic selling of currency and trigger a currency crisis (Shimpalee \& Breuer, 2006). Chang (2007) also argues that when foreign lenders are pessimistic about a country's political stability, they could significantly increase the interest on debts. ${ }^{2}$ This exacerbates the insolvency position of the country and thereby increasing the likelihood of a sovereign debt crisis. Based on these arguments, we expect that political instability is associated with higher probability of financial crises.

Finally, with regard to government support, Azzimonti (2019) argues that government policies play a vital role in reducing the probability of a financial crisis by implementing macro-prudential policies or by undertaking necessary reforms. However, due to the associated political costs, policymakers could have different views about the costs in comparison with the benefits of these policies or reforms. Such conflicts create obstacles for a government to change or implement necessary policies or reforms against economic shocks. The split in the legislature reflected by the percentage of government seats can influence the ability of politicians to affect the economic 
environment (Redl, 2020). Minority governments will face more difficulties in adopting preventive policies or necessary reforms because they require the consent of the incumbent party and opposition parties. This means that they could face policy gridlock, which strongly reduces their abilities to quickly react to economic shocks, resulting in a higher probability of financial crises (Bechtel, 2009; Krehbiel, 1998). Moreover, mainstream opposition parties may choose to further weaken the incumbent party rather than to co-operate for the nation's sake. De Giorgi, Moury, and Ruivo (2014) examine the behaviour of minority and majority governments in Portugal for austerity measures during pre-crisis periods and find that mainstream opposition parties are more adversarial when they are getting more chances of replacing the incumbent government. Therefore, we formulate the hypothesis that majority governments are associated with lower probability of financial crises.

\section{3 | FINANCIAL CRISIS IDENTIFICATION}

Before analysing the role of the political environment on the unfolding of financial crises, we need to identify the different types of crises. We discuss below how they are identified and how the respective variables are defined to be used later in the empirical analysis.

\section{1 | Systemic banking crisis}

We use Laeven and Valencia's (2020) database for the identification of systemic banking crises. Existing studies also rely on this database to identify those crises. ${ }^{3}$ Laeven and Valencia $(2008,2013,2020)$ identify systemic banking crises based on the intensity of policy interventions. They argue that financial distress turns into a systemic banking crisis when at least three out of six policy interventions are significant. ${ }^{4}$

\section{2 | Currency crisis}

Frankel and Rose (1996) were the first to identify a currency crisis based on the depreciation of a currency. A currency crisis occurs when the nominal depreciation of the domestic currency vis a vis US dollar exceeds $25 \%$ a year. They avoid counting a depreciation as an independent crisis by a requirement that the change in the exchange rate must be higher than the previous year's change by at least 10 percentage points. Laeven and Valencia $(2008,2013,2020)$ adjust the threshold of 25 to
$30 \%$. They allow a 5-year window for episodes that meet the two conditions for several continuous years to reduce the likelihood of counting the same crises. We borrow from Laeven and Valencia $(2008,2013,2020)$ to identify currency crises. Unlike their method using the end-ofperiod exchange rate, we use the average exchange rate, consistent with Frankel and Rose (1996) and Eichengreen, Rose, and Wyplosz (1996). In that sense, as our method may identify currency crises too late, we add 1 year prior to crisis episodes if Laeven and Valencia (2020) identify them as crisis episodes.

\section{3 | Sovereign debt crisis}

Previous studies identify a sovereign debt crisis when a country fails to meet its principals or interest payments on the due date, or when the country postpones its obligations by rescheduling debts with less favourable terms (see, among others, De Bonis et al., 1999; Detragiache \& Spilimbergo, 2001; Reinhart \& Rogoff, 2014). However, due to the lack of data on worldwide sovereign defaults, existing studies face three problems. First, most studies have examined sovereign debt crises in a limited group of countries (De Bonis et al., 1999; Phillips \& Shi, 2019). Second, some studies only focus on external debt crises or domestic debt crises (Balteanu \& Erce, 2018; Detragiache \& Spilimbergo, 2001; Ishihara, 2005). ${ }^{5}$ Third, most studies rely on a few sources of sovereign defaults, which undermines the real size of sovereign defaults and, consequently, provides false identifications of sovereign debt crises (Laeven \& Valencia, 2013, 2020; Manasse \& Roubini, 2009). For these reasons, we use the sovereign defaults database of the Credit Rating Assessment Group (CRAG) published by the Bank of Canada and the Bank of England. CRAG is the first worldwide database of sovereign defaults that contain both domestic and external sovereign defaults for all types of creditors (Beers \& Mavalwalla, 2018). We define sovereign debt crises as episodes in which either total sovereign defaults exceed $1 \%$ of GDP in at least three consecutive years or total sovereign defaults exceed 7\% of GDP. The first year that either of these conditions meets is the start year of a sovereign debt crisis. A debt crisis ends when total sovereign defaults, including debt restructuring or rescheduling as a share of GDP, is smaller than $1 \%$. For the first condition, we use the threshold of $1 \%$ of GDP to remove sovereign defaults that are negligible, which is consistent with Balteanu and Erce (2018). The second condition is provided because we find that all sovereign debt crises occurring in less than 3 years have the lowest degree of default is 7\% of GDP. To detect any missing crisis episodes, the results are compared with the sovereign debt crisis 
database of Laeven and Valencia (2020); the two conditions cover all crisis episodes identified by them.

\section{4 | Twin and triple crises}

Following Laeven and Valencia (2008, 2013, 2020), we define a twin crisis in year $t$ when a banking crisis in year $t$ is preceded by or followed by a currency or sovereign debt crisis within $[t-1, t+1]$. This definition clearly shows how a banking crisis is followed, coincided or preceded by a currency or sovereign debt crisis. Similarly, a triple crisis is identified when a banking crisis in year $t$ follows or precedes a currency and sovereign debt crisis during the period $[t-1, t+1]$. Using the same approach, currency and sovereign debt crises are set at time $t$ to identify other variations of twin and triple crises. For the three types of crises identified above (bank, currency and debt) we construct a dummy variable that takes the value of 1 in the years in which the respective crises are occurring (and 0 otherwise); for twin and triple crises, the dummy takes the value of 1 in the years in which a type of crisis coincides with or is preceded and/or followed by another type (and 0 otherwise). In addition, we also construct a dummy variable for "all crises," which takes the value of 1 when any type of financial crisis occurs in a given year, and 0 otherwise.

\section{I DATA AND METHODOLOGY}

\section{1 | Data and variables}

Due to data availability, our study is limited to the period 1975-2017. Our sample data covers a maximum of 85 countries, depending on the type of financial crises. ${ }^{6}$ Our panel is unbalanced because most variables do not contain information for some countries/years. Data for political variables (electoral cycle, political ideology, political stability and government support) are extracted from the World Bank's Database of Political Institutions (DPI, 2017). ${ }^{7}$ The macroeconomic variables were obtained from the World Development Indicators (WDI, 2019) and International Financial Statistics (IFS, 2019). ${ }^{8,9}$

To account for the role of the political environment on the likelihood of financial crises and their types, we employ the following variables:

1. Political ideology: RIGHTGOV; LEFTGOV; CENTREGOV. These dummy variables take the values of 1 when the incumbent government is formed by the right wing, left wing or centre parties, respectively, and 0 otherwise. Right-wing governments could reduce the likelihood of financial crises as they tend to pursue friendly and reliable investment policies, are more concerned with sustainable development and have strong connections with industrial associations and firms; however, their greater willingness to deregulate the economy may play the opposite effect in this dynamic.

2. Year after election (YAFELECTION). This dummy variable takes the value of 1 in the election year and the year after the election, and 0 otherwise. The "honeymoon hypothesis" states that new policies tend to be implemented in the immediate aftermath of elections, leading to the higher risk of major policy shifts; hence, crises might be more likely after elections.

3. The time a chief executive is in office (YEXEOFFICE). This variable counts the number of years that a chief executive stays in office. As a longer tenure allows incumbent chief executives to pursue the announced policies, the risk of instability and policy changes is lower. Hence, it is expected longer tenures will reduce the probability of financial crises.

4. Majority government (MAJORGOV). This dummy variable takes the value of 1 when an incumbent government has more than half of the seats in the legislature or parliament. It is expected that majority governments are less likely to face policy gridlock and, hence they might be more able to implement preventive policies or necessary reforms to stabilize economic conditions and avoid crises.

The economic variables were selected from the relevant literature on financial crises to control for the most relevant economic factors to the timing of financial crises. The following economic variables are used in our model:

1. The prevalence of a fixed exchange rate regime (EXREGIME) is expected to expose the domestic currency to a higher likelihood of a speculative attack. Less flexible exchange rate regimes allow speculators to profit when central banks abandon the pegs and allow the exchange rates to float (Eichengreen et al., 1996). Hence, the likelihood of financial crises, especially currency crises, is expected to be more likely under those regimes.

2. The effects of capital account openness (KAOPEN) on financial crises are inconclusive. Free capital mobility improves the efficiency of the allocation of resources (Edwards, 1999), which creates social welfare and benefits trading activities as well as the investment environment (Chamon \& Garcia, 2016). However, capital controls can be used to enhance financial stability such as preventing sudden stops or capital flights (Devereux \& Yu, 2018; Farhi \& 
Werning, 2014; Forbes, Fratzscher, \& Straub, 2015; Magud, Reinhart, \& Rogoff, 2018).

3. Credit growth (PSCGROWTH) can signal financial crises as mismanaged credit expansions that turned into credit booms or asset bubbles, which can cause a banking crisis when they burst (Demirguc-Kunt \& Detragiache, 1998, 2002, 2005). Empirical evidence shows that credit booms often precede financial crises (see, e.g., Falcetti \& Tudela, 2006; Fielding \& Rewilak, 2015; Perugini et al., 2016).

4. The relationship between trade openness (TRADE/ GDP) and financial crises is controversial. Countries with high levels of trade openness are more exposed to shocks from the international markets (Kaminsky \& Reinhart, 1999). Conversely, more opened countries can be in a better position to service their external debts through revenues from their exported products and services (Detragiache \& Spilimbergo, 2001).

5. Real GDP growth (RGDPGROW) is introduced as an explanatory variable in the financial crises equation because it reflects the overall economic performance. Faster growth generates more cash flows and attracts investment (Demirguc-Kunt \& Detragiache, 1998, 2002; $\mathrm{Yu}, 2016)$ and increases aggregate demand (Perugini et al., 2016). Conversely, slow developments in the real side of the economy are a major source of financial instability (Demirguc-Kunt \& Detragiache, 1998, 2002). Overall, it is expected that better economic performance reduces the likelihood of financial crises.

6. Inflation rate (INFLATION) is a proxy of macroeconomic uncertainty. High levels of inflation indicate the mismanagement of macroeconomic and monetary policies, which is a source of economic uncertainty and financial crises (Demirguc-Kunt \& Detragiache, 1998, 2002; Eichengreen et al., 1996).

7. Current account balance as a percentage of GDP (CUACC/GDP) is used to account for external vulnerabilities. A country that has large external imbalances (deficits) is more reliant on external capital flows (Falcetti \& Tudela, 2006) and, therefore, might be more vulnerable to financial crises.

8. Government debt as a percentage of GDP (GOVDEBT/GDP) is a variable of extreme importance, especially in what concerns to the rise of a sovereign debt crisis. Previous studies are consistent in showing that higher levels of government debt are positively associated with financial (debt) crises (Balteanu \& Erce, 2018; Dreher, Herz, \& Karb, 2006; Reinhart \& Rogoff, 2011, 2014).

9. US real interest rate (USRATE) is used as a proxy of the global interest rate. An increase in the international interest rate is associated with higher capital outflows (Falcetti \& Tudela, 2006; Kaminsky et al., 1998), which represents an additional burden on debt repayments of debtor countries (Yu, 2016). Consequently, it may also be linked to an increase in the likelihood of financial crises.

10. Bank deposits as a percentage of GDP (DEPOSIT/GDP) is another important indicator as it can signal bank runs and the loss of depositors' faith in the banking system. When investors wish to withdraw their deposits and transfer funds abroad, there will be increased pressure on the exchange rate markets, which could trigger a currency crisis (Kaminsky et al., 1998).

11. Finally, foreign reserves as a percentage of GDP (RESERVES/GDP) are another important indicator of financial crises, especially currency ones, because reserves can be used to finance eventual increases in exchange market pressure. The occurrence of a currency crisis depends on whether a central bank has sufficiently large international reserves to defend speculative attacks or not (Berg \& Pattillo, 1999; Kaminsky et al., 1998). Moreover, foreign reserves are a reliable indicator of a country's ability to deal with debt repayments.

\section{2 | Econometric methodology}

A panel data logit model is used to assess the determinants of financial crises. A special emphasis is put on the neglected role of political factors. ${ }^{10}$ Country fixed effects are controlled for to account for the possibility that the likelihood of financial crises could change cross-country independently of the explanatory variables. ${ }^{11}$ Time effects are also controlled for with decade-dummy variables, which is consistent with Castro and Martins (2018). As financial crises tend to come in waves (Laeven \& Valencia, 2020), year-dummies may not only fail to capture such effects but imply the loss of observations when there is limited data variability.

According to the literature and our conjectures regarding the potential role of the political environment, we assume that the probability of financial crises (and each of their types) is a function of political and economic factors:

$$
\operatorname{Pr}(\text { FinCrises })=f(\text { Pol, Econ }),
$$

where FinCrises refers to the different types of financial crises (banking, currency, sovereign, twin and triple, and all crises). As defined in Section 3, this variable takes the value of 1 in the years in which the respective type of crises is ongoing, and 0 otherwise. Pol corresponds to the vector of political factors, and Econ is the vector of economic controllers. 
The logit model implies that Equation (1) can be expressed as follows:

$$
\operatorname{Pr}\left(\text { FinCrises }_{i, t}=1 \mid \boldsymbol{P o l}_{i, t}, \text { Econ }_{i, t-1}\right)=\Lambda\left(\boldsymbol{\alpha}^{\prime} \boldsymbol{P o l}_{i, t}+\boldsymbol{\beta}^{\prime} \boldsymbol{E} \boldsymbol{c o n}_{i, t-1}\right),
$$

are the vectors of parameters to be estimated; $\Lambda($.$) is the$ logistic cumulative distribution function $\Lambda(z)=e^{z} /(1$ $\left.+e^{z}\right)$. The structural logit model for panel data is then defined as:

$$
\begin{gathered}
y_{i, t}^{*}=\boldsymbol{\alpha}^{\prime} \boldsymbol{P o l}_{i, t}+\boldsymbol{\beta}^{\prime} \boldsymbol{E c o n}_{i, t-1}+v_{i}+\tau_{t}+\varepsilon_{i, t}, \\
\text { FinCrises }_{i, t}=\left\{\begin{array}{c}
1 \text { if } y_{i, t}^{*}>0 \\
0 \text { otherwise }
\end{array}\right.
\end{gathered}
$$

where $y_{i, t}^{*}$ is the unobserved latent variable of financial crises; $v_{i}$ and $\tau_{\mathrm{t}}$ account for country- and time-specific effects and $\varepsilon_{i, t}$ is error term for country $i$ at time $t$. Ignoring heterogeneity generates the usual omitted variable bias, leading to inconsistent estimates. We address this issue by employing the fixed-effects logit model.

\section{5 | EMPIRICAL ANALYSIS}

The estimation results are presented in this section. We start by discussing the main findings, which are then corroborated by a sensitivity analysis and robustness checks. As a final exercise, we focus the analysis only on the onset of financial crises.

\section{1 | Main findings}

To examine the effects of the economic and political factors on the likelihood of financial crises, we start by considering: pooled, fixed-effects (FE) and random effects (RE) logit, and instrumental variables probit (IV-Probit) models. Our favoured econometric method is the FE logit model as it accounts for time-invariant unobservable country factors and time effects. ${ }^{12,13}$ The overall performance of the FE logit estimator is superior to the other methods, providing the smallest values for the Schwartz Bayesian information criterion (SBIC). The Hausman test also favours this method as more efficient than RE and pooled logit.

Endogeneity is a concern for studies with financial crises because economic factors could be the manifestation of economic recessions caused by financial crises themselves. To mitigate this potential reverse causality or simultaneity problem, economic control variables are lagged 1 year. ${ }^{14}$ This procedure also accounts for eventual delays in reporting economic data. We further control for endogeneity by estimating an IV-Probit model. ${ }^{15}$ As the Wald exogeneity test fails to reject the exogeneity hypothesis (1-year lags of) the economic factors appear to be exogenous. In order to detect the presence of multi-collinearity, we compute the correlation between the independent variables and find that all the correlation coefficients are smaller than $|0.25|$ except the one between the variables KAOPEN and DEPOSIT/GDP, which is 0.44 . This suggests that, in general, our selected variables show remarkably little correlation and do not foreshadow a serious multi-collinearity problem.

The main empirical findings of this paper using the conditional FE logit model are reported in Table $1 .{ }^{16}$ The estimated coefficients on most of the economic variables show their usual signs and significance. As predicted and observed in the literature, financial crises are more likely to occur when: (a) international reserves (RESERVES/ GDP) decrease; (b) capital accounts (KAOPEN) are more restricted; (c) current account deficit (CUACC/GDP) is higher; (d) real economic growth (RGDPGROW) slows down; and (e) the level of government debt (GOVDEBT/ GDP) is higher. Surprisingly, a more flexible exchange rate regime (EXREGIME) seems to raise the likelihood of financial crises. This finding is opposite to previous studies (Eichengreen et al., 1996; Shimpalee \& Breuer, 2006). This could be because a fixed exchange rate regime improves monetary discipline and thereby promotes macroeconomic performance and investor confidence in the long run.

Moving to the main novelties of this paper, political factors have proved to play an important role in explaining the likelihood of different types of financial crises. However, their effects on financial crises in general ("all crises" specification) are statistically insignificant. This shows that it is necessary to dig deeper into individual types of financial crises not only to understand how they evolve but, most importantly, to unveil the role of the political factors on their development/mitigation.

As expected, banking and currency crises are more likely to occur within 1 year after elections (YAFELECTION), which is consistent with the "honeymoon hypothesis." On average, the probability of currency and banking crises is $32 \%$ higher within the first year after elections. New policies or reforms could be implemented in the immediate aftermath of elections leading to the greater economic uncertainty from policy changes and a higher likelihood for those types of crises to thrive. ${ }^{17}$ Moreover, banking crises are more likely to occur within the first year after elections because governments may postpone bailouts of inefficient banks. As voters believe that using taxpayers' money to finance 


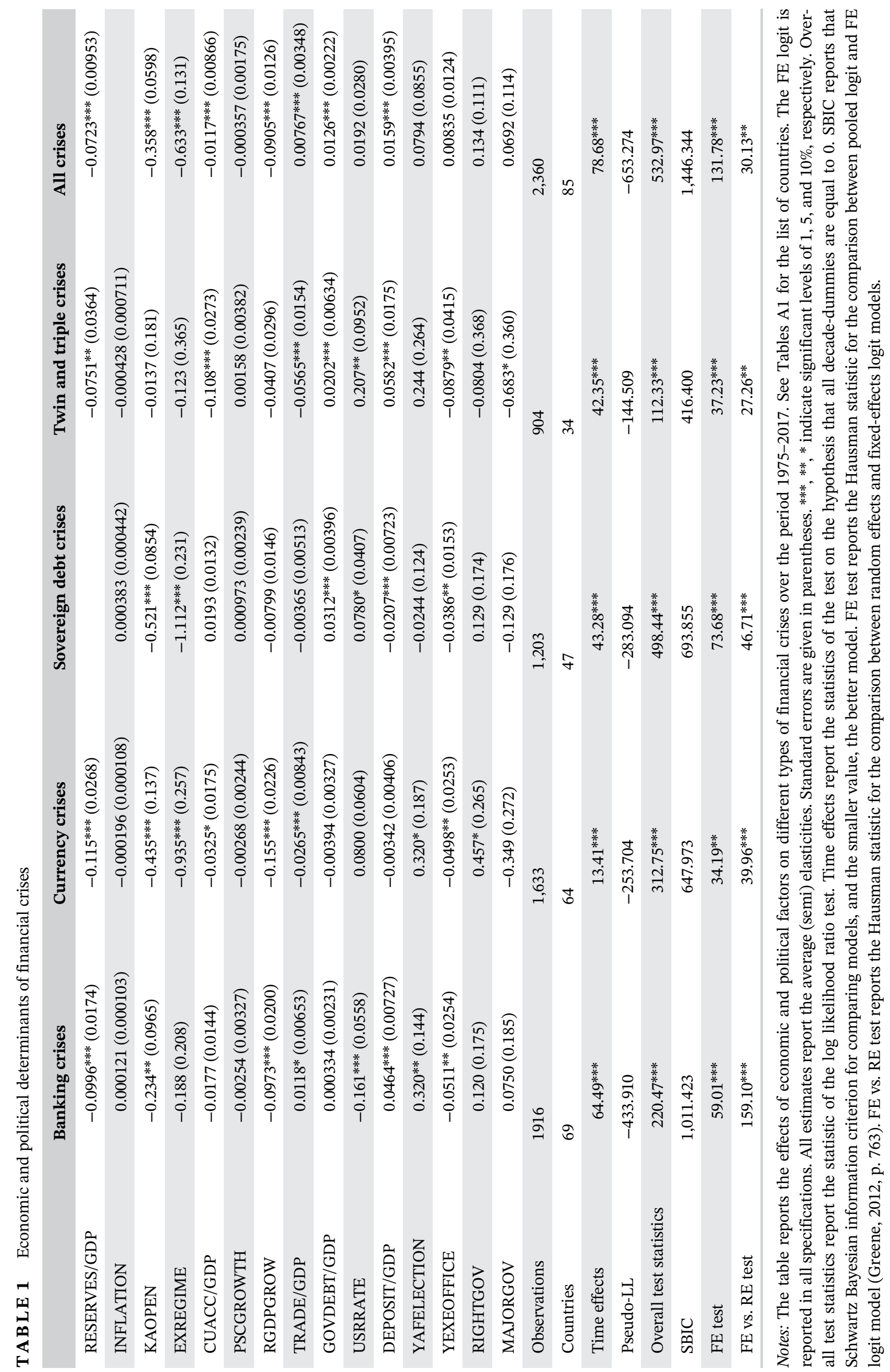


bailouts is a waste of money, revealing real costs of bailouts could negatively influence the chance of being reelected. Brown and Dinc (2005) find that half of banks' takeovers or closing down of inefficient ones are undertaken within the first year after elections in emerging countries during the 1990s, whereas the figure for government rescues within 1 year before elections is only $10 \%$.

Among all the political variables, the tenure of chief executives (YEXEOFFICE) turns out to be particularly relevant for any of the types of financial crises analysed. The more time a chief executive stays in office, the lower the probability of any type of those financial crises will be. This means that the proposed hypothesis that political instability is associated with higher probability of financial crises receives clear empirical support. In particular, an additional year in office decreases the probability of any type of financial crisis by around 5\%, on average and ceteris paribus. These findings are in line with the work by Dreher et al. (2006), Aisen and Veiga (2013), and Shimpalee and Breuer (2006), who argue that a longer tenure of incumbent executives allows them to continue their announced programmes and policies. This reduces the political and economic uncertainties, which in turn lowers the likelihood of a financial crisis.

Additionally, we find that the probability of currency crises is higher when incumbent governments are formed by right-wing parties. This finding is, however, inconsistent with our expectations that right-wing governments pursue stable and friendly economic policies to promote economic development. Perhaps right-wing governments tend to refrain necessary economic reforms during precrisis periods, resulting in the higher likelihood of currency crises (Galasso, 2014). Moreover, they are also more prone to promote economic freedom and freedom of trade (Castro \& Martins, 2019), which might facilitate the contagion of these crises, making them more likely.

Finally, MAJORGOV appear to have a relevant influence on twin and triple crises. In line with our hypothesis, twin and triple crises are less likely to occur when incumbent governments have an absolute majority of seats in the legislature or parliament. Among political variables, the impact of majority governments on twin and triple crises is critical. In particular, majority governments reduce the probability of twin and triple crises on average by more than $68 \%$, ceteris paribus. Majority governments are less likely to face policy gridlock and, consequently, they are more able to implement preventive policies or necessary reforms during fragile periods.

However, it is noteworthy that the effects of majority governments on single financial crisis are insignificant. Perhaps, incumbent governments may have fewer incentives to implement preventive policies or reforms because citizens will punish and replace them if they fail in stabilizing the economy against shocks, especially when the next election is imminent. If majority governments are formed by unstable coalition governments, they are more likely to be replaced by mainstream opposition parties. As highlighted by Leblang and Satyanath (2006), coalition governments and opposition parties tend to exacerbate economic conditions to increase their chances of winning the next election instead of co-operating with the incumbent party for nation's sake. Unless the detrimental impacts of financial crises are severe, as in the cases of twin and triple crises, incumbent governments may have less incentive to implement costly preventive policies in "single" financial crises. This lends support to Drazen and Grilli (1993), who argue that the severity of economic conditions could be a necessary condition to achieve social consensus for the adoption of major policy reforms.

\section{2 | Sensitivity analysis}

To check for the sensitivity of our main findings to changes in the model specifications, we run additional regressions using alternative measures for the political factors. Tables 2 and 3 present the results for the sensitivity analyses. The estimated coefficients, signs, impact and relevance of all economic control variables are consistent with those reported in Table 1.

With respect to the alternative measures of political factors, the electoral cycle is now proxied in Table 2 by three dummy variables: the first year after the election (Y1AFELECTION), the election year (YEARELECTION) and the year before the election (Y1BELECTION). The coefficients of YAFELECTION presented in Table 1 reveal that the probability of banking and currency crises is higher within 1 year after elections. This variable includes the year of election, which include periods before and after elections, and the year after the election. With these three dummy variables, we can better locate whether financial crises significantly arise in the election year, before or after.

The results in Table 2 show that banking crises are more likely to occur in election years. This, coupled with the findings of YAFELECTION (see Table 1), implies that electoral effects on banking crises are stronger immediately after elections. As argued by Brown and Dinc (2005), governments tend to postpone bank bailouts when elections are approaching because revealing the real costs of the bailouts could influence their chance of re-election.

Another proxy that we use to measure the degree of political stability is the percentage of veto players who leave the government in any given year (STAB). The 


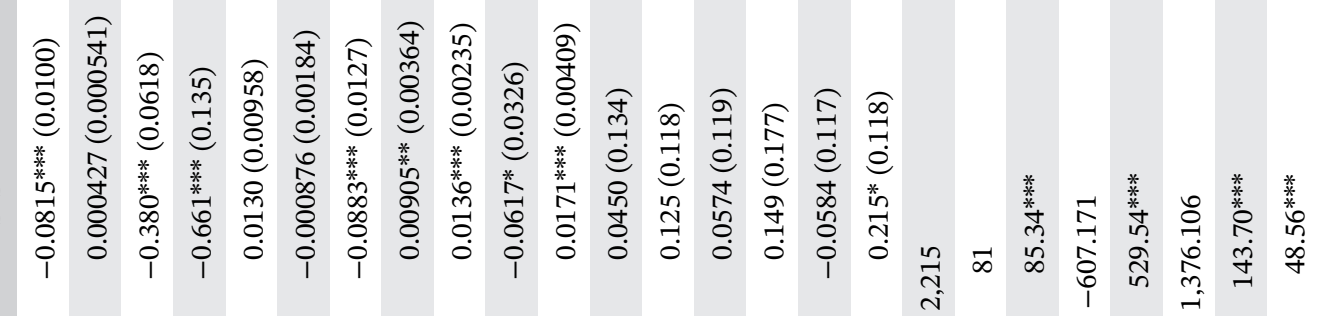

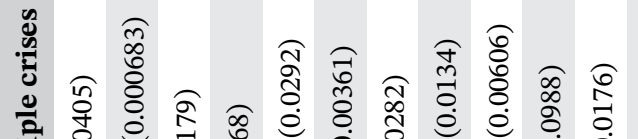

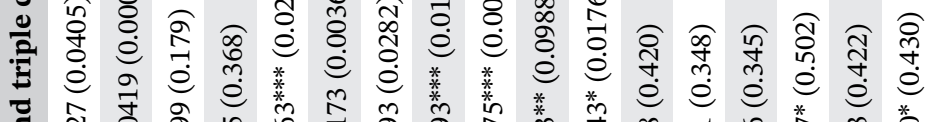

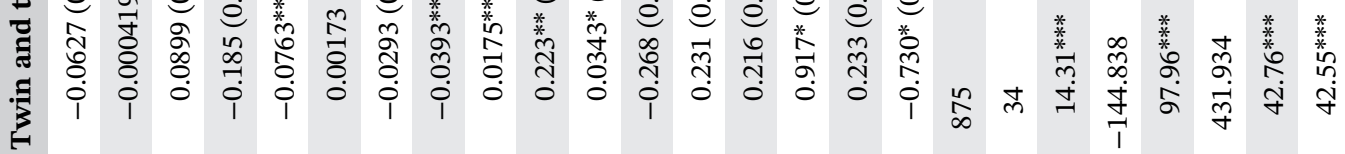

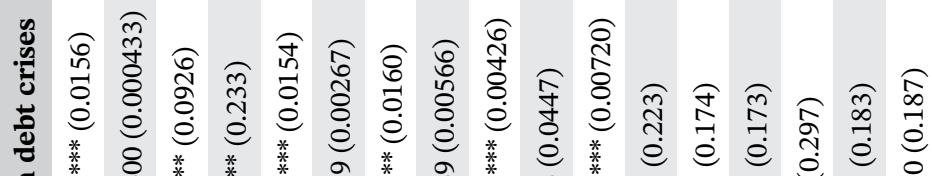

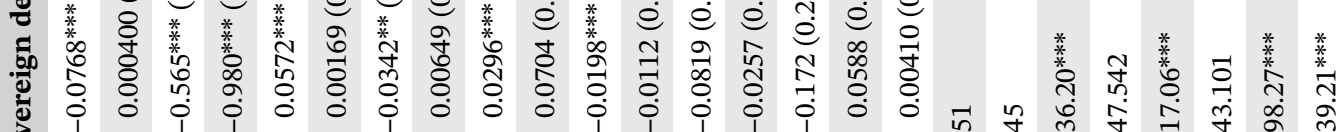

苟 $\begin{aligned} & 0 \\ & \dot{0}\end{aligned}$

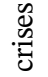

. 준

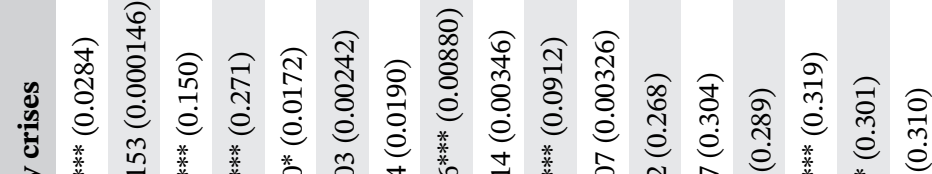

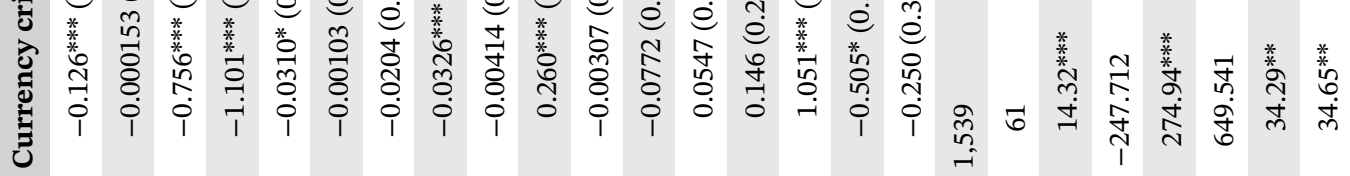

ฮี

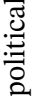

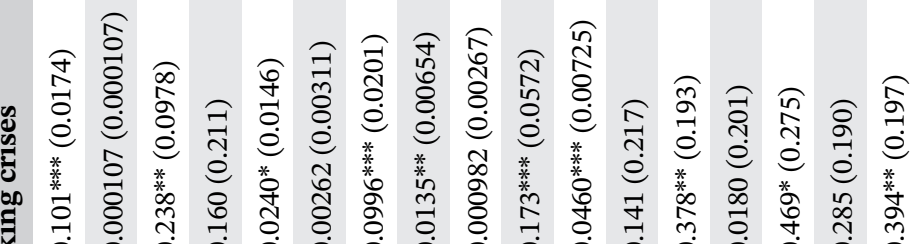

就

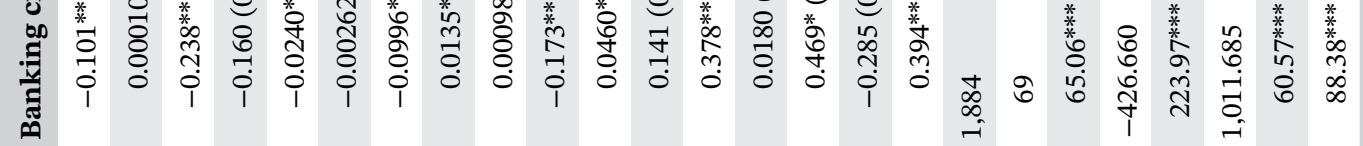

产

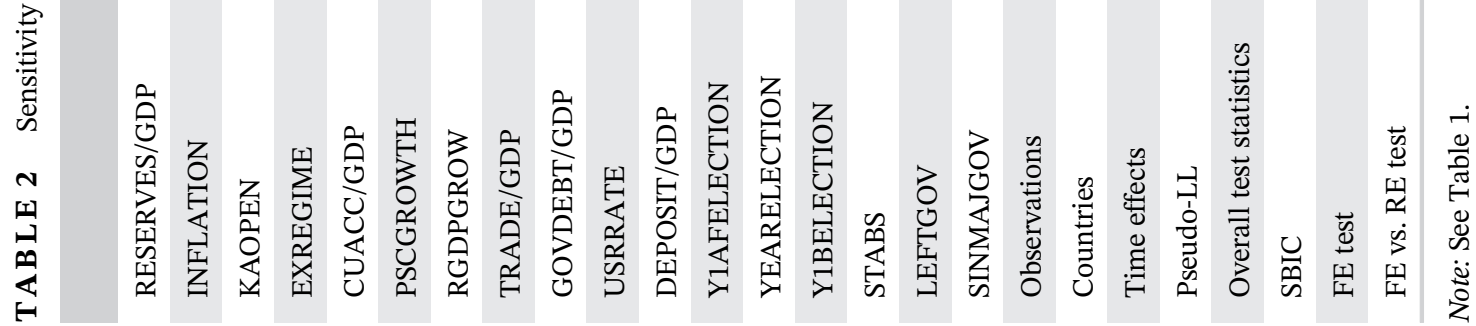




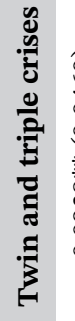

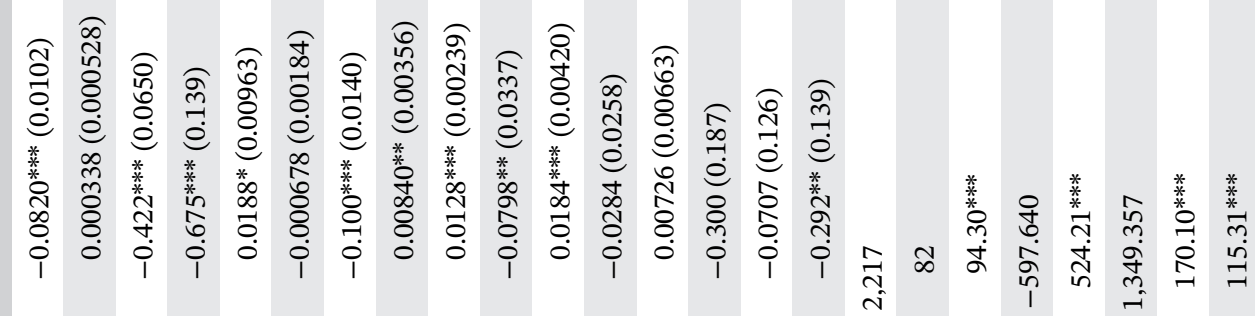

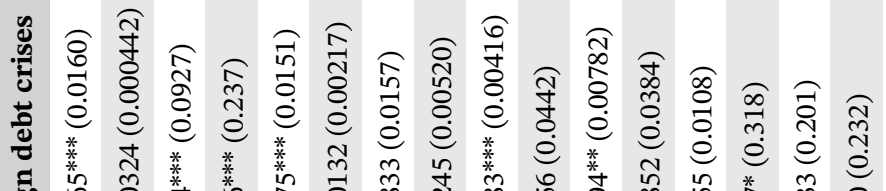

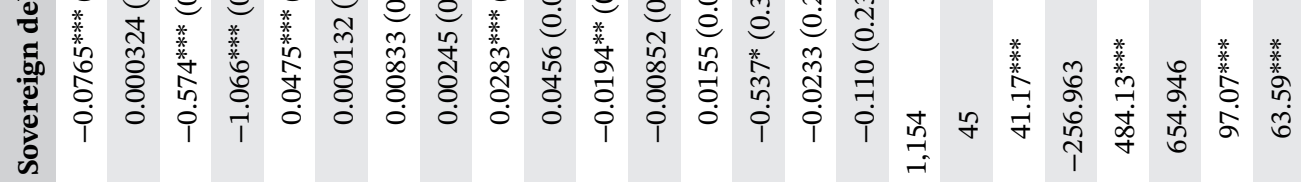

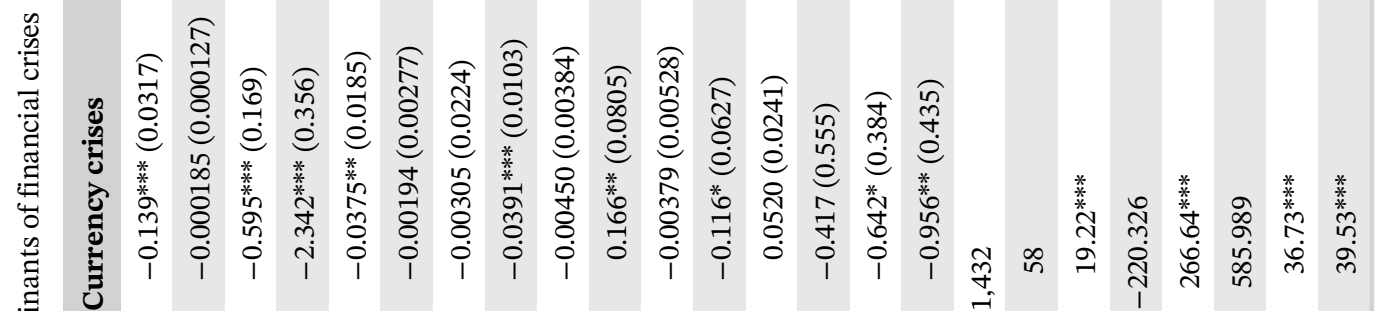

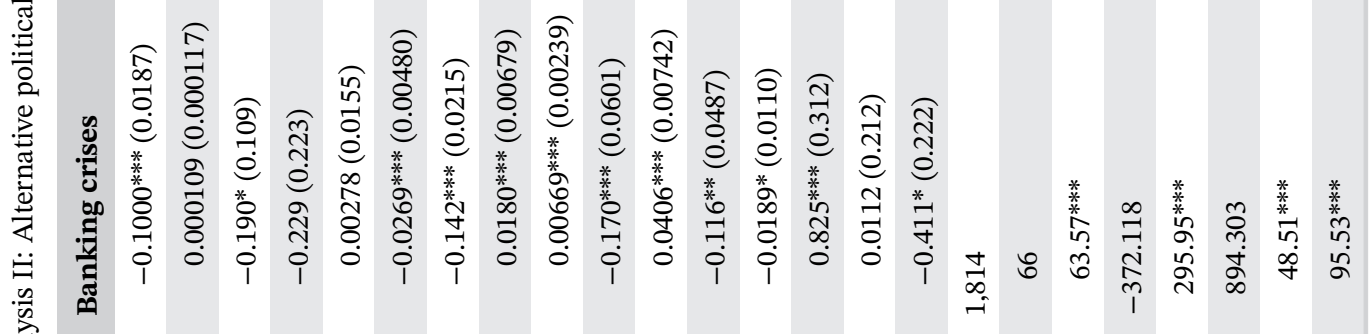

量

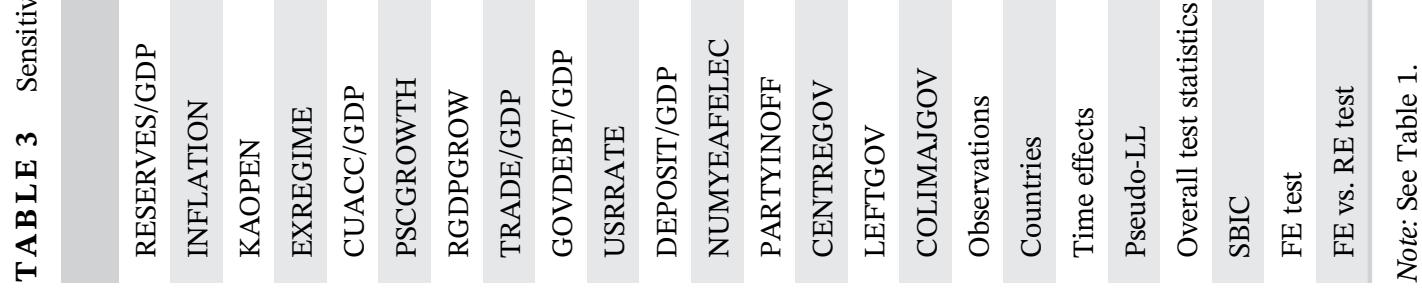


changes in the head of governments or governing groups can be associated with higher political instability and the probability of financial crises (Rivoli \& Brewer, 1997; $\mathrm{Yu}, 2016)$. As expected, banking, currency, and twin and triple crises are more likely to occur when the percentages of veto players leaving the government increase. This is because new governing groups taking office could implement major policy shifts, which result in higher economic uncertainty caused by increased risks of policy changes.

The results also show that the effects of left-wing governments (LEFTGOV) on the probability of currency crises are opposite with those of right-wing governments (see Table 1). In particular, currency crises are less likely to occur when the incumbent governments are formed by the left wing. As right-wing governments tend to refrain necessary economic reforms (Galasso, 2014), the inverse was expected to happen with the LEFTGOV.

Regarding government support, an incumbent MAJORGOV can be formed by either a single majority government (SINMAJGOV) or two or more coalition majority governments (COLIMAJGOV). Banking and financial crises, in general, are more likely to occur when incumbent governments are formed by a single majority government. As argued by Colomer (2012) and Finer (1982), single majority governments can be strongly socially biased. Their economic and social policies can be influenced by minority interest groups and not encompass broad social preferences. However, single majority governments appear to reduce the likelihood of twin and triple crises, which is consistent with the previous findings on majority governments. The severity of economic conditions associated with twin and triple crises, compared to a single-event financial crisis, could be a condition for majority governments to implement necessary reforms for the nation's sake (Drazen \& Grilli, 1993).

To further check the sensitivity of political determinants of financial crises, Table 3 reports the second sensitivity analysis with alternative measures of political factors. YAFELECTION is replaced by the number of years after elections (NUMYEAFELEC) to account for the increased likelihood of financial crises after elections. The results indicate that the probability of banking and currency crises is lower when the number of years after elections increases. This corroborates the findings that banking and currency crises and more likely to occur within 1 year after elections.

With respect to political stability, the tenure of incumbent executives (YEXEOFFICE) is replaced by the tenure of incumbent parties (PARTYINOFF). We find that an additional year that an incumbent party stays in office leads to a reduction in the probability of banking crises, which is consistent with the previous findings on the effects of the tenure of incumbent executives. However, its effects on other types of financial crises are statistically insignificant. It could be argued that the implications of party tenure on financial crises are less significant than those of executive tenure. This might be the case because the risk of policy changes can also arise due to changes in chief executives even though they belong to the same party.

Centre governments (CENTREGOV) and left governments dummies are added simultaneously to provide a more comprehensive view on the impact of political ideology. The results are also consistent with previous ones: currency crises are more likely to occur when right-wing governments stay in office, and the inverse holds for LEFTGOV.

Moving to political support, we find that majority governments formed by (COLIMAJGOV) are associated with a lower probability of any type of financial crises, except debt crises. There is robust evidence that majority governments reduce the likelihood of twin and triple crises. However, while single majority governments increase the probability of financial crises, coalition majority governments show an opposite effect. This could explain why the overall effects of MAJORGOV on the probability of single-event financial crises are insignificant. This finding is in line with Colomer (2012) and Bawn and Rosenbluth (2006), who show that majority governments formed by coalition governments produce more stable economic policies. This, in turn, may reduce the probability of crises.

\section{3 | Robustness checks}

To control for the possibility that our main findings are influenced by the heterogeneous groups of countries in our sample, we divide the analysis into two groups: advanced economies and emerging/developing countries. $^{18}$ Table 4 reports the results for both groups of countries. As developed countries are less likely to experience currency, sovereign debt, and twin and triple crises (consequently, the number of observations is very low), this analysis focuses on the emerging and developing countries; for advanced economies we only report the results for banking and financial crises in general ("all crises"). ${ }^{19}$

Again, the effects of the political factors on the probability of financial crises, in general, are statistically insignificant in both groups of countries, which further confirm the need to dig deeper into different types of financial crises. Most of the political effects observed in the two groups of countries are consistent with the main findings in Table 1. It can be concluded that our findings 


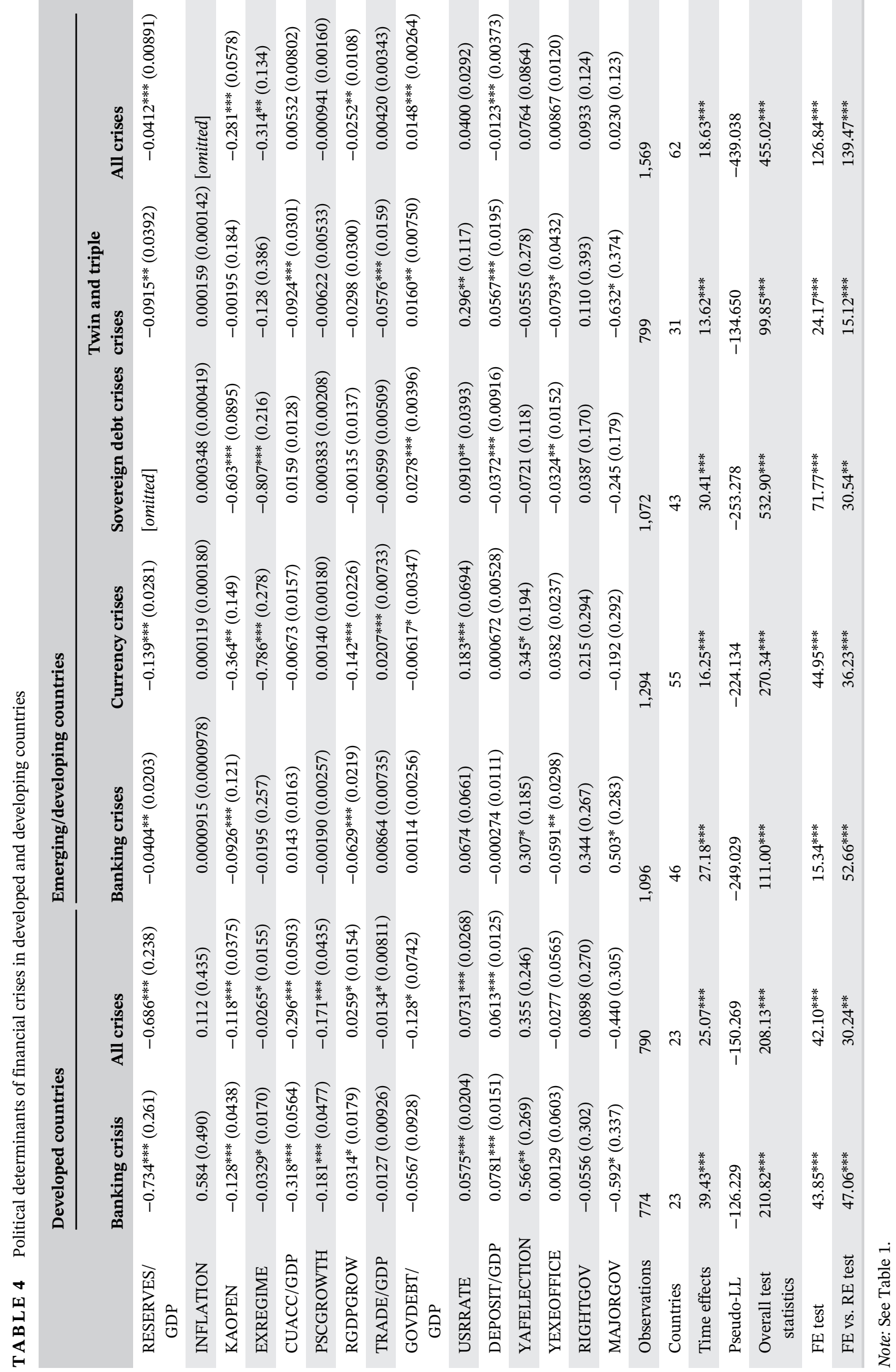


are less likely to be influenced by the eventual heterogeneity between these two groups of countries. The only exception is the impact of majority governments on systemic banking crises. Majority governments increase the probability of banking crises in emerging and developing countries, whereas they reduce the likelihood of banking crises in advanced countries. It is likely that single majority governments, which associate with higher levels of policy instability (Bawn \& Rosenbluth, 2006; Colomer, 2012), are more popular in emerging and developing countries; moreover, they might have a political agenda that is influenced by a strong minority group of interests that might lead to unbalanced social, economic and financial policies. In contrast, majority governments in developed countries are more likely to be formed by coalition parties, which provides better scrutinized and more stable economic policies.
The second set of robustness tests is provided in Table 5, where the sequencing effects of financial crises are taken into account. Financial crises could not be single events. They tend to come in waves and influence each other. It is important to control for the possibility that one type of financial crises is influenced by others.

Our results show that different types of financial crises do influence each other. In particular, a banking crisis is more likely to arise when a currency crisis is ongoing; but banking crises also lead to an increase in the probability of a currency crisis. Hence, banking and currency crises might precede each other. However, the impact of a banking crisis on a currency crisis is higher than the inverse effect. The sequencing effects between currency and debt crises are also positive and significant, indicating that the occurrence of one of them increases the probability of the other unfolding. The effects of debt

T A B L E 5 Sequencing effects

\begin{tabular}{|c|c|c|c|}
\hline & Banking crisis & Currency crisis & Debt crisis \\
\hline RESERVES/GDP & $-0.0921^{* * *}(0.0180)$ & $-0.106^{* * *}(0.0271)$ & \\
\hline INFLATION & $0.000134(0.000130)$ & $-0.000234^{* *}(0.000113)$ & $0.000405(0.000432)$ \\
\hline KAOPEN & $-0.178^{*}(0.101)$ & $-0.401^{* * *}(0.139)$ & $-0.489 * * *(0.0878)$ \\
\hline EXREGIME & $-0.0885(0.214)$ & $-0.844^{* * *}(0.264)$ & $-1.024^{* * *}(0.234)$ \\
\hline CUACC/GDP & $0.00262(0.0152)$ & $-0.0301 *(0.0179)$ & $0.0283^{* *}(0.0132)$ \\
\hline PSCGROWTH & $-0.00297(0.00318)$ & $-0.00278(0.00257)$ & $0.000572(0.00272)$ \\
\hline RGDPGROW & $-0.127^{* * *}(0.0197)$ & $-0.138^{* * *}(0.0231)$ & $-0.0188(0.0147)$ \\
\hline TRADE/GDP & $0.0124 *(0.00652)$ & $-0.0316^{* * *}(0.00877)$ & $-0.00123(0.00524)$ \\
\hline GOVDEBT/GDP & $0.00237(0.00256)$ & $-0.00418(0.00323)$ & $0.0331^{* * *}(0.00406)$ \\
\hline USRRATE & $-0.153^{* * *}(0.0575)$ & $0.175^{* *}(0.0871)$ & $0.0701 *(0.0418)$ \\
\hline DEPOSIT/GDP & $0.0433^{* * *}(0.00726)$ & $-0.00570(0.00484)$ & $-0.0207^{* * *}(0.00721)$ \\
\hline YAFELECTION & $0.305^{* *}(0.148)$ & $0.345^{*}(0.193)$ & $-0.0197(0.126)$ \\
\hline YEXEOFFICE & $-0.0604^{* *}(0.0268)$ & $-0.0440 *(0.0257)$ & $-0.0385^{* *}(0.0156)$ \\
\hline RIGHTGOV & $0.0540(0.181)$ & $0.489^{*}(0.281)$ & $0.0869(0.178)$ \\
\hline MAJORGOV & $0.0896(0.189)$ & $-0.389(0.287)$ & $-0.0754(0.180)$ \\
\hline CURRENCRISIS & $0.896^{* * *}(0.268)$ & & $1.035^{* * *}(0.263)$ \\
\hline DEBTCRISIS & $0.384(0.297)$ & $1.039^{* * *}(0.344)$ & \\
\hline BANKCRISIS & & $1.041^{* * *}(0.286)$ & $0.00857(0.241)$ \\
\hline Observations & 1909 & 1,623 & 1,203 \\
\hline Countries & 69 & 64 & 47 \\
\hline Time effects & $60.59^{* * *}$ & $16.42^{* * *}$ & $45.51^{* * *}$ \\
\hline Pseudo-LL & $-409.20^{* * *}$ & -238.230 & -271.915 \\
\hline Overall test statistics & $270.69^{* * *}$ & $340.67^{* * *}$ & $520.80^{* * *}$ \\
\hline FE test & $64.46^{* * *}$ & $33.76^{* *}$ & $74.09^{* * *}$ \\
\hline FE vs. RE test & $70.43^{* * *}$ & $36.18^{* *}$ & $126.17^{* * * *}$ \\
\hline
\end{tabular}

Notes: See Table 1. Estimations controlling for crisis sequencing effects over the period 1975-2017 using fixed-effects logit model. 


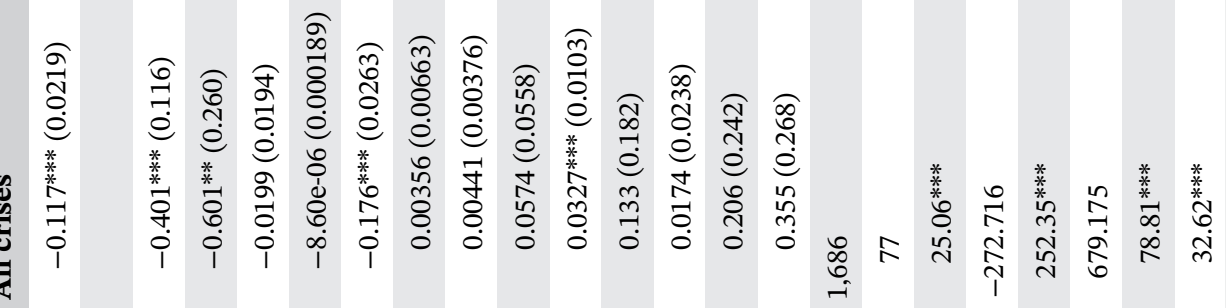

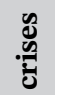

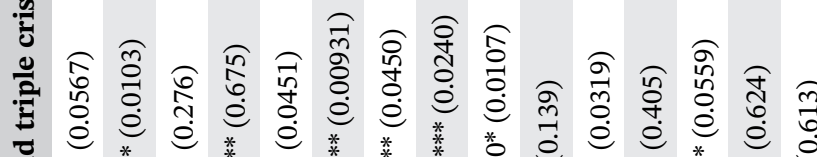

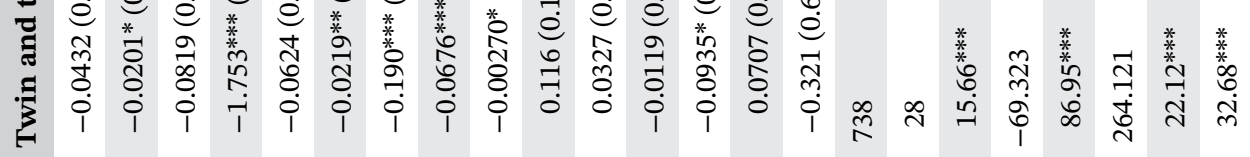

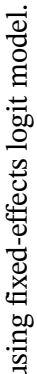

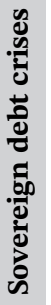

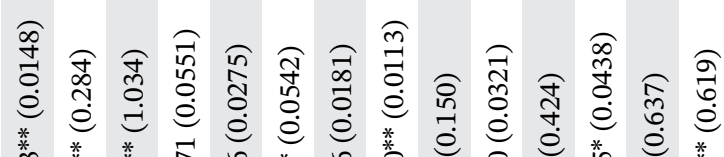

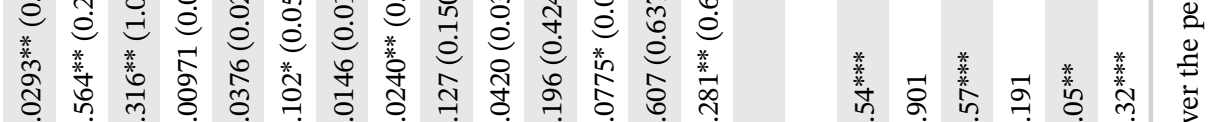

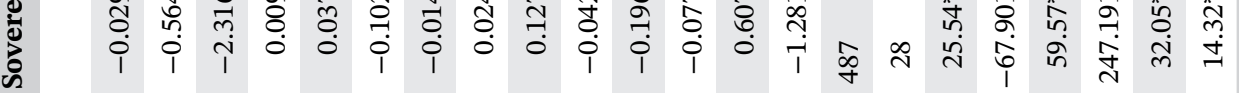

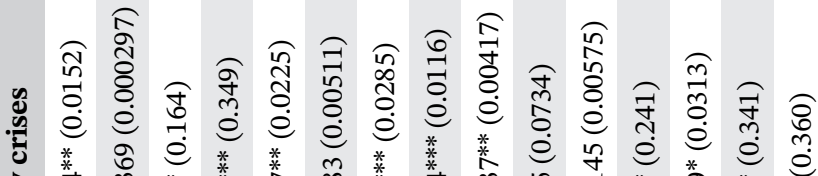

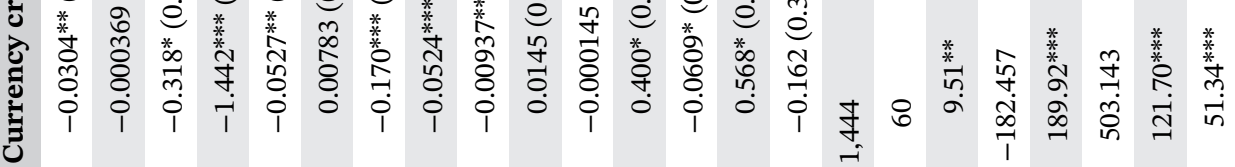

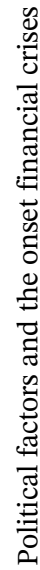

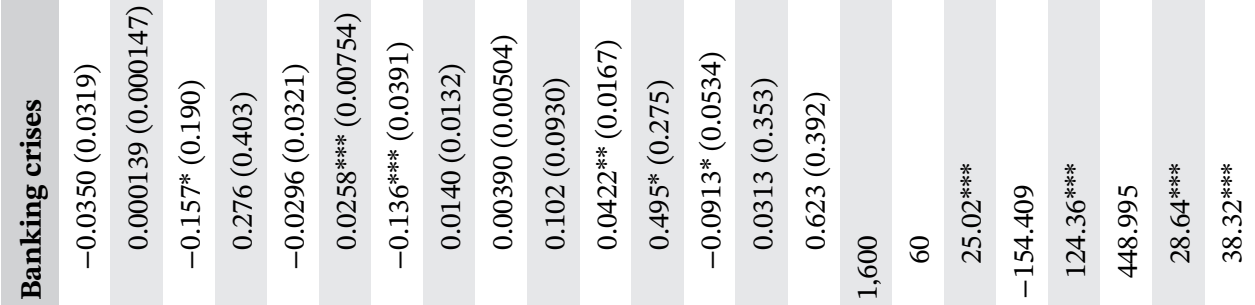

0
0
0
0
0
0
0
0

吾

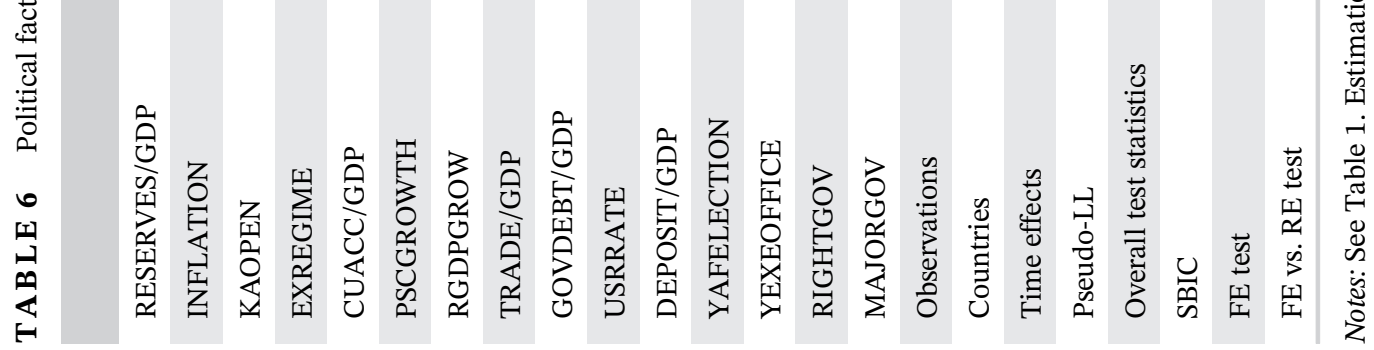


crises on banking crises and the inverse effects are statistically insignificant. This is reasonable as we identify only seven twin crises relating to debt and banking crises over the period 1970-2017.

\section{4 | Political factors and the onset of financial crises}

As mentioned earlier, we use lags of all economic variables to mitigate endogeneity problems. ${ }^{20}$ To further control for endogeneity, we borrow from Demirguc-Kunt and Detragiache (1998) the idea of focusing only on the onset of financial crises and tranquil periods. All observations for the length of financial crises are removed except the year of their onset. This means that our FinCrises dummy is now equal to 1 only in the year in which the respective type of crises arises. This is done to avoid that the behaviour of economic and political factors could be influenced by the development of the financial crises themselves. The drawback of this method is that several years of observations are lost.

Table 6 reports the results for the onset of financial crises using a FE logit model. The regressions show that the impact of economic and political variables on the onset of financial crises is consistent with the main findings provided above. In particular, banking and currency crises are more likely to occur within 1 year after elections. Again, an additional year in office of incumbent executives increases the probability of any type of financial crises arising. Moreover, the likelihood of currency crises is higher when incumbent governments are formed by right-wing parties. All the coefficient signs on majority governments are consistent with the main findings. However, the effects of majority governments on twin and triple crises are statistically insignificant despite carrying the same coefficient sign.

Overall, these results for the onset of financial crises corroborate the main conclusions of the analysis provided above regarding the role that the political environment can play in the timing of different types of financial crises.

\section{6 | CONCLUSIONS}

Different types of financial crises have repeatedly occurred all over the world. To tackle their occurrence, it is important to understand their drivers. Using a FE logit model over a sample of 85 countries for the period 1975-2017, this paper examines the effects of political factors on the probability of financial crises. This is the first attempt to provide a comprehensive view of the implications of electoral cycle, political ideology, political stability and government support on the likelihood of different types of financial crises.

We find that systemic banking and currency crises are more likely to occur within 1 year after elections, giving support to the "honeymoon hypothesis." New policies and reforms tend to be implemented in the immediate aftermath of elections and, hence, generate higher economic uncertainty, which can turn into financial crises. In addition, governments may postpone necessary interventions and boost the economy when elections are approaching to enhance the chances of being re-elected.

Our results also indicate that a longer tenure of incumbent executives reduces the likelihood of financial crises. Among political variables, this factor exerts a consistent and statistically significant impact on all types of financial crises. By staying in office for longer, they can carry on with the announced programmes. This lowers political and economic uncertainty caused by policy changes, and thus reduces the probability of financial crises.

Currency crises are more likely to occur when rightwing governments are in office. It could be argued that right-wing governments tend to refrain from implementing necessary economic reforms during precrisis periods given their higher propensity to promote economic freedom, which in turn increases the likelihood of currency crises. Furthermore, there are robust findings that majority governments reduce the likelihood of twin and triple crises. This might be due to the fact that majority governments, holding an absolute majority of seats in the parliament, would face fewer policy gridlocks to implement necessary preventive policies or economic reforms against economic shocks.

These findings survive sensitivity analyses and robustness checks. They indicate that political factors are important drivers of financial crises. However, an important message here is that the political effects only become evident when we dig deeper into the analysis of the different types of financial crises. Our findings suggest that policymakers should pay careful attention to the developments of the economic environment in the aftermath of elections, and when right-wing governments take office. They should also work together to promote political stability and political cohesion, especially during times of crises. This is not an easy task but could have helped countries like Argentina and Greece to avoid more prolonged and severe crises. The length and severity of crises are issues that we intend to explore in future research.

\section{ACKNOWLEDGEMENT}

The authors would like to thank Alistair Milne for his very insightful comments and suggestions. 


\section{ORCID}

\section{Thanh C. Nguyen (1) https://orcid.org/0000-0002-9688- 0748 \\ Vitor Castro (1) https://orcid.org/0000-0002-6426-6663}

\section{ENDNOTES}

${ }^{1}$ Glaeser, Tella, and Llach (2018) argue that long-lasting recessions and repeated financial crises in Argentina are not attributable to external factors but political reasons. Political factors are the main origins of various inconsistent and inefficient economic policies and reforms in Argentina.

${ }^{2}$ Chang (2007) defines political instability as the divergence between policymakers' objectives for debt repayment and those of the electorate. In the sense that chief executives are frequently changed, the objectives can be inconsistent.

${ }^{3}$ See, for example, Caprio Jr. et al. (2014), Fielding and Rewilak (2015), Kim et al. (2013), and Perugini et al. (2016). Chaudron and de Haan (2014) are the first to compare the reliability of different systemic banking crisis databases by examining four banking crisis events: the United States savings and loan crisis during the 1980s; the Japanese banking crisis in the 1990s, the Norwegian banking crisis during the early 1990s, and the Turkish crisis in the late 1990s. Based on the data from bank failures and losses, they find that Laeven and Valencia's $(2008,2013)$ banking crisis database is more accurate than those by Caprio Jr., Klingebiel, Laeven, and Noguera (2005), and Reinhart and Rogoff (2009).

${ }^{4}$ Six policy interventions are designed to cover all the responses of a government to a systemic banking crisis; for further details see Honohan and Laeven (2005) and Laeven and Valencia (2008).

${ }^{5}$ As noted by Reinhart and Rogoff (2014), there is a growing trend that emerging market governments are more reliant on debts denominated in domestic currency. This means that examining only external debts can ignore a larger number of domestic debt crises, and this explains why many sovereign debt crises are unnoticed.

${ }^{6}$ The list of countries in our samples can be found in Table A1.

${ }^{7}$ See Beck, Clarke, Groff, Keefer, and Walsh (2001).

${ }^{8}$ The definition for each variable and respective data source is listed in Table A2. Table A3 reports descriptive statistics for financial crises dummies and all the variables used in this study. Note that we observe a 35\% share of country-year observations for all types of financial crises. However, when we look at the different types, the share varies substantially from around $8 \%$ for currency and banking crises to $28 \%$ for debt crises. This high share of country-year observations for debt crises is due to the fact that many sovereign debt crises in emerging and developing countries last for several decades. In particular, they have sovereign defaults exceeding 1\% of GDP for many years. It is noteworthy that unlike banking and currency crises, the long duration of debt crises can be a result of the unwillingness to pay rather than the incapability to pay (De Bonis et al., 1999; Reinhart \& Rogoff, 2009, p. 54). A decision of default is associated with reputational damage and possible sanctions as well as output losses (Arellano, 2008, Reinhart \& Trebesch, 2016). However, as many countries have already been insolvent, they are unwilling to repay their debts as the benefits of being defaults can outweigh their relative costs (Manasse \& Roubini, 2009).

${ }^{9}$ The data that support the findings of this study are available from the corresponding author upon reasonable request.

${ }^{10}$ The logit model has been widely employed to study the incidence of banking crises (Bordo, Eichengreen, Klingebiel, \& MartinezPeria, 2001; Demirguc-Kunt \& Detragiache, 2005), currency crises (Bordo et al., 2001; Eichengreen, Rose, \& Wyplosz, 1995) and sovereign debt crises (Reinhart \& Rogoff, 2011; Yu, 2016).

${ }^{11}$ Controlling for country-fixed effects implies that those variables that do not vary over time end up being excluded from the model. Moreover, countries that did not experience a particular type of financial crises will be removed from the sample in the estimation process.

${ }^{12}$ Some studies use the conditional fixed effects logit model to explore the incidence of financial crises but ignore the influence of time effects. See, for example, Von Hagen and Ho (2007) and Yu (2016).

${ }^{13}$ The FE logit model can be expressed as: $y_{i, t}^{*}=c_{i} d_{i, t}+\boldsymbol{\alpha}^{\prime}$ Pol $_{i, t}+\boldsymbol{\beta}^{\prime}$ Econ $_{i, t-1}+\tau_{t}+\varepsilon_{i, t} ; \quad y_{i, t}=1$ if $y_{i, t}^{*}>0$, and 0 otherwise, where $c_{\mathrm{i}}$ is constant term, $d_{i, t}$ is a dummy variable that takes the value 1 for country $i$ and 0 otherwise, $y_{i, t}$ is financial crisis, $y_{i, t}^{*}$ is unobserved latent variable.

${ }^{14}$ Previous studies have also used economic variables lagged one period to examine the economic determinants of financial crises. See, e.g., Dreher et al. (2006), Bordo et al. (2001), and Laeven and Valencia (2008).

${ }^{15}$ Instruments for the IV-probit are the lagged 2 years for economic variables. Full outcomes of the estimations using different econometric methods are available upon request.

${ }^{16}$ Partial/marginal effects cannot be obtained from the FE logit model (Wooldridge, 2010, p. 622). Hence, we interpret the results of the FE logit model based on the average (semi-) elasticities, as suggested by Kitazawa (2012) and Kemp and Silva (2016).

${ }^{17}$ Krueger (1993, p. 124) reports two circumstances that financial reforms tend to be implemented: (a) A new government taking office implement reforms to realize their benefits before the next election; (b) A government perceives an economic crisis and implements reforms.

${ }^{18}$ These two groups of countries are identified based on the country classifications of World Economic Outlook. For details, see https://www.imf.org/external/pubs/ft/weo/2018/02/weodata/ groups.htm.

${ }^{19}$ In our dataset, advanced countries experienced only nine currency crises, four sovereign debt crises, and three twin and triple crises over the period 1975-2017.

${ }^{20}$ Note that, as mentioned before, we also estimated an IV-probit to address eventual endogeneity issues. Nevertheless, the Wald exogeneity tests rejected the endogeneity hypothesis. Those results are not reported here but they are available upon request.

\section{DATA AVAILABILITY STATEMENT}

The data that support the findings of this study are available from the corresponding author upon reasonable request. 


\section{REFERENCES}

Abiad, A., \& Mody, A. (2005). Financial reform: What shakes it? What shapes it? American Economic Review, 95, 66-88.

Aidt, T., Castro, V., \& Martins, R. (2018). Shades of red and blue: Government ideology and sustainable development. Public Choice, 175, 303-323.

Aisen, A., \& Veiga, F. J. (2013). How does political instability affect economic growth? European Journal of Political Economy, 29, 151-167.

Alesina, A. (1987). Macroeconomic policy in a two-party system as a repeated game. Quarterly Journal of Economics, 102, 651-678.

Alesina, A., Roubini, N., \& Cohen, G. (1997). Political cycles and the macroeconomy. Cambridge, MA: MIT Press.

Arellano, C. (2008). Default risk and income fluctuations in emerging economies. American Economic Review, 98, 690-712.

Azzimonti, M. (2019. November). Partisan conflict, news, and investors' expectations' (Working Paper No. 2019-07). Stony Brook University.

Balteanu, I., \& Erce, A. (2018). Linking bank crises and sovereign defaults: Evidence from emerging markets. IMF Economic Review, 66, 617-664.

Barth, J. R., Caprio, G., \& Levine, R. (2004). Bank regulation and supervision: What works best? Journal of Financial Intermediation, 13, 205-248.

Bawn, K., \& Rosenbluth, F. (2006). Short versus long coalitions: Electoral accountability and the size of the public sector. American Journal of Political Science, 50, 251-265.

Bechtel, M. M. (2009). The political sources of systematic investment risk: Lessons from a consensus democracy. The Journal of Politics, 71, 661-677.

Beck, T., Clarke, G., Groff, A., Keefer, P., \& Walsh, P. (2001). New tools in comparative political economy: The database of political institutions. World Bank Economic Review, 15, 165-176.

Beers, D., \& Mavalwalla, J. (2018. July). The BoC-BoE sovereign default database revisited: What's new in 2018? (Staff Working Paper No. 739). Bank of England.

Berg, A., \& Pattillo, C. (1999). Are currency crises predictable? A test. IMF Staff Papers, 46, 107-138.

Bialkowski, J., Gottschalk, K., \& Wisniewski, T. P. (2008). Stock market volatility around national elections. Journal of Banking \& Finance, 32, 1941-1953.

Bordo, M., Eichengreen, B., Klingebiel D., Martinez-Peria, M.S., \& Rose, A.K. (2001). Is the crisis problem growing more severe? Economic Policy, 16, 51-82.

Brauninger, T., \& Bernhagen, P. (2005). Structural power and public policy: A signaling model of business lobbying in democratic capitalism. Political Studies, 53(1), 43-64.

Brown, C. O., \& Dinc, I. S. (2005). The politics of bank failures: Evidence from emerging markets. The Quarterly Journal of Economics, 120, 1413-1444.

Burgoon, B., Demetriades, P., \& Underhill, G. R. D. (2012). Sources and legitimacy of financial liberalisation. European Journal of Political Economy, 28, 147-161.

Caprio, G., Jr., D'Apice, V., Ferri, G., \& Puopolo, G. W. (2014). Macro-financial determinants of the grate financial crisis: Implications for financial regulation. Journal of Banking \& Finance, 44, 114-129.
Caprio, G., Jr., Klingebiel, D., Laeven, L., \& Noguera, G. (2005). Appendix: Banking crisis database. In P. Honoda \& L. Laeven (Eds.), Systemic financial crises: Containment and resolution. Cambridge, UK: Cambridge University Press.

Castro, V., \& Martins, R. (2018). Political and institutional determinants of credit booms. Oxford Bulletin of Economics and Statistics, 81, 1144-1178.

Castro, V., \& Martins, R. (2019). The political ideology of economic freedom. Unpublished Manuscript.

Chamon, M., \& Garcia, M. (2016). Capital controls in Brazil: Effective? Journal of International Money and Finance, 61, 163-187.

Chang, R. (2007). Financial crises and political crises. Journal of Monetary Economics, 54, 2409-2420.

Chaudron, R., \& de Haan, J. (2014. January). Identifying and dating systemic banking crises using incidence and size of bank failure (DNB Working Papers No. 406). Netherlands Central Bank.

[dataset] Chinn, M. D., \& Ito, H. (2017). Chinn-Ito capital account openness. Retrieved from http://web.pdx.edu/ ito/

Colomer, J. M. (2012). The more parties, the greater policy stability. European Political Science, 11, 229-243.

De Bonis, R., Giustiniani, A., \& Gomel, G. (1999). Crises and bailouts of banks and countries: Linkages, analogies, and differences. The World Economy, 22, 55-86.

De Giorgi, E., Moury, C., \& Ruivo, J. P. (2014). 'Incumbents, opposition and international lenders: Governing Portugal in times of crisis. Journal of Legislative Studies, 21, 54-74.

Demirguc-Kunt, A., \& Detragiache, E. (1998). The determinants of banking crises in developing and developed counties. IMF Staff Papers, 45, 81-109.

Demirguc-Kunt, A., \& Detragiache, E. (2002). Does deposit insurance increase banking system stability? An empirical investigation. Journal of Monetary Economics, 49, 1373-1406.

Demirguc-Kunt, A., \& Detragiache, E. (2005). Cross-country empirical studies of systemic bank distress: A survey. National Institute Economic Review, 192, 68-83.

Detragiache, E., \& Spilimbergo, A. (2001. January). Crises and liquidity: Evidence and interpretation (IMF Working Paper No. WP/01/2).

Devereux, M. B., \& Yu, C. (2018). Evaluating the role of capital controls and monetary policy in emerging market crises. Journal of International Money and Finance, 95, 189-211.

[dataset] DPI. (2017). Database of political institutions. World Bank. Retrieved from https://datacatalog.worldbank.org/dataset/ wps2283-database-political-institutions

Drazen, A., \& Grilli, V. (1993). 'The benefit of crises for economic reforms. The American Economic Review, 83, 598-607.

Dreher, A., Herz, B., \& Karb, V. (2006). Is there a causal link between currency and debt crises? International Journal of Finance and Economics, 11, 305-325.

Edwards, S. (1999). How effective are capital controls? Journal of Economic Perspectives, 13, 65-84.

Eichengreen, B., Rose, A. K., \& Wyplosz, C. (1995). The antecedents and aftermath of speculative attacks. Economic Policy, 10, 249-312.

Eichengreen, B., Rose, A. K., \& Wyplosz, C. (1996). Contagious currency crises: First tests. The Scandinavian Journal of Economics, 98, 463-484. 
Falcetti, E., \& Tudela, M. (2006). Modelling currency crises in emerging markets: A dynamic probit model with unobserved heterogeneity and autocorrelated errors. Oxford Bulletin of Economics and Statistics, 68, 445-470.

Farhi, E., \& Werning, I. (2014). Dilemma not trilemma? Capital controls and exchange rates with volatile capital flows. IMF Economic Review, 62, 569-605.

Fielding, D., \& Rewilak, J. (2015). Credit booms, financial fragility and banking crises. Economics Letters, 136, 233-236.

Finer, S. E. (1982). Adversary politics and the eighties. Electoral Studies, 1, 221-230.

Forbes, K., Fratzscher, M., \& Straub, R. (2015). 'Capital-flow management measures: What are they good for? Journal of International Economics, 96, 76-97.

Frankel, J. A., \& Rose, A. K. (1996). Currency crashes in emerging markets: An empirical treatment. Journal of International Economics, 41, 351-366.

Galasso, V. (2014). The role of political partisanship during economic crises. Public Choice, 158, 143-165.

[dataset] GDD. (2018). Global debt database. International Monetary Fund. Retrieved from https://www.imf.org/external/ datamapper/datasets/GDD

[dataset] GFD. (2017). Global financial development. World Bank. Retrieved from https://databank.worldbank.org/source/globalfinancial-development

Glaeser, E. L., Tella, R. D., \& Llach, L. (2018). Introduction to argentine exceptionalism. Latin American Economic Review, 27, 1-22.

Goodhart, C. A. E. (2011). The macro-prudential authority: Powers, scope and accountability. OECD Journal: Financial Market Trends, 2011, 1-26.

Greene, W. H. (2012). Econometric analysis (7th ed.). Harlow, England; New York, NY: Pearson Education Limited.

Hibbs, D. A. (1977). Political parties and macroeconomic policy. The American Political Science Review, 71, 1467-1487.

Hibbs, D. A. (1987). The American political economy: Macroeconomics and electoral politics in the United States. Cambridge, MA: Harvard University Press.

Honohan, P., \& Laeven, L. (2005). Systemic financial crises: Containment and resolution. Cambridge, England: Cambridge University Press.

[dataset] IFS. (2019). International financial statistics. International Monetary Fund. Retrieved from http://data.imf.org/?sk= 4C514D48-B6BA-49ED-8AB9-52B0C1A0179B

[dataset] Ilzetzki, E., Reinhart, C. M., \& Rogoff, K. S. (2017). Exchange rate regime Ilzetzki, Reinhart, and Rogoff classification. Retrieved from https://carmenreinhart.com/exchange-rate/

Ishihara, Y. (2005. June). Quantitative analysis of crisis: Crisis identification and causality (World Bank Policy Research Working Paper No. 3598).

Jens, C. E. (2017). Political uncertainty and investment: Casual evidence from U.S. gubernatorial elections. Journal of Financial Economics, 124, 563-579.

Julio, B., \& Yook, Y. (2012). Political uncertainty and corporate investment cycles. Journal of Finance, 67, 45-83.

Kaminsky, G. L., Lizondo, S., \& Reinhart, C. M. (1998). Leading indicators of currency crises. IMF Staff Papers, 45, 1-48.

Kaminsky, G. L., \& Reinhart, C. M. (1999). The twin crises: The causes of banking and balance-of-payments problems. The American Economic Review, 89, 473-500.
Kelly, B., Pástor, L., \& Veronesi, P. (2016). The price of political uncertainty: Theory and evidence from the option market. Journal of Finance, 71, 2417-2480.

Kemp, G., \& Silva, J. S. (2016, September). Partial effects in fixedeffects models. Paper presented at United Kingdom Stata Users' Group Meeting 2016, Stata Users Group.

Kim, T., Koo, B., \& Park, M. (2013). Role of financial regulation and innovation in the financial crisis. Journal of Financial Stability, 9, 662-672.

Kitazawa, Y. (2012). Hyperbolic transformation and average elasticity in the framework of the fixed effects logit model. Theoretical Economics Letters, 2, 192-199.

Krehbiel, K. (1998). Pivotal politics. A theory of U.S. law-making. Chicago, IL: University of Chicago Press.

Krueger, A. O. (1993). Political economy of policy reform in developing countries. Cambridge: MIT Press.

Laeven, L., \& Valencia, F. (2008. September). Systemic banking crises: A new database (IMF Working Paper No. WP/08/224).

Laeven, L., \& Valencia, F. (2013). Systemic banking crises database. IMF Economic Review, 61, 225-270.

Laeven, L., \& Valencia, F. (2020). Systemic banking crises database II. IMF Economic Review, 68, 307-361.

Leblang, D., \& Satyanath, S. (2006). Institutions, expectations, and currency crises. International Organization, 60, 245-262.

Magud, N. E., Reinhart, C. M., \& Rogoff, K. S. (2018). Capital controls: Myth and reality. Annals of Economics and Finance, 19, 1-47.

Manasse, P., \& Roubini, N. (2009). "Rules of thumb" for sovereign debt crises. Journal of International Economics, 78, 192-205.

Nordhaus, W. (1975). The political business cycle. Review of Economic Studies, 42, 169-190.

Pástor, L., \& Veronesi, P. (2012). Uncertainty about government policy and stock prices. Journal of Finance, 67, 1219-1264.

Perugini, C., Holscher, J., \& Collie, S. (2016). Inequality, credit and financial crises. Cambridge Journal of Economics, 40, 227-257.

Phillips, P. C. B., \& Shi, S. (2019). Detecting financial collapse and ballooning sovereign risk. Oxford Bulletin of Economics and Statistics, 81, 1336-1361.

Pickering, A., \& Rockey, J. (2011). Ideology and the growth of government. Review of Economics and Statistics, 93, 907-919.

Pickering, A. C., \& Rockey, J. (2013). Ideology and the size of US state government. Public Choice, 156, 443-465.

Redl, C. (2020). Uncertainty matters: Evidence from close elections. Journal of International Economics, 124, 1-16.

Reinhart, C. M., \& Rogoff, K. S. (2009). 'This time is different: Eight centuries of financial folly, Princeton New Jersey : Princeton University Press.

Reinhart, C. M., \& Rogoff, K. S. (2011). From financial crash to debt crisis. American Economic Review, 101, 1676-1706.

Reinhart, C. M., \& Rogoff, K. S. (2014). This time is different: A panoramic view of eight centuries of financial crises. Annals of Economics and Finance Society for AEF, 15, 1065-1188.

Reinhart, C. M., \& Trebesch, C. (2016). Sovereign debt relief and its aftermath. Journal of the European Economic Association, 14, 215-251.

Rivoli, P., \& Brewer, T. L. (1997). Political instability and country risk. Global Finance Journal, 8, 309-321. 
Rogoff, K. (1990). Equilibrium political budget cycles. American Economic Review, 801, 21-36.

Rogoff, K., \& Sibert, A. (1988). Elections and macroeconomic policy cycles. Review of Economic Studies, 55(1), 16.

Shimpalee, P. L., \& Breuer, J. B. (2006). Currency crises and institutions. Journal of International Money and Finance, 25, $125-145$.

Snowberg, E., Wolfers, J., \& Zitzewitz, E. (2007). Partisan impacts on the economy: Evidence from prediction markets and close elections. Quarterly Journal of Economics, 122, 807-829.

Vaugirard, V. (2007). Bank bailouts and political instability. European Journal of Political Economy, 23, 821-837.

Veiga, F. J., \& Veiga, L. G. (2004). Popularity functions, partisan effects, and support in parliament. Economics and Politics, 16, 101-115.

Von Hagen, J., \& Ho, T.-K. (2007). Money market pressure and the determinants of banking crises. Journal of Money, Credit and Banking, 39, 1037-1066.

[dataset] WDI. (2019). World development indicators. World Bank. Retrieved from https://databank.worldbank.org/source/worlddevelopment-indicators [dataset] WEO. (2019). World economic outlook. International Monetary Fund. Retrieved from https://www.imf.org/external/ pubs/ft/weo/2019/01/weodata/download.aspx

Wooldridge, J. M. (2010). Econometric analysis of cross section and panel data (2nd ed.). Cambridge, MA: The MIT Press.

Yonce, A. (2015). US corporate investment over the political cycle. Quarterly Journal of Finance, 5, 1-37.

Yu, S. (2016). The effect of political factors on sovereign default. Review of Political Economy, 28, 397-416.

\section{SUPPORTING INFORMATION}

Additional supporting information may be found online in the Supporting Information section at the end of this article.

How to cite this article: Nguyen TC, Castro V, Wood J. Political environment and financial crises. Int J Fin Econ. 2022;27:417-438. https://doi.org/10. $\underline{1002 / \text { ijfe. } 2160}$

T A B LE A1 List of countries (1975-2017)

\begin{tabular}{|c|c|c|c|c|}
\hline Albania 235 & Costa Rica ${ }^{12345}$ & Honduras ${ }^{235}$ & Mexico $^{12345}$ & Solomon Islands ${ }^{35}$ \\
\hline Algeria ${ }^{12,345}$ & Croatia $^{15}$ & Hungary $^{15}$ & Moldova $^{12345}$ & South Africa ${ }^{2345}$ \\
\hline Angola $^{235}$ & Cyprus $^{135}$ & Iceland $^{1245}$ & Mozambique $^{125}$ & Spain $^{125}$ \\
\hline Argentina $^{12345}$ & Czech Rep ${ }^{15}$ & India $^{15}$ & Netherlands ${ }^{15}$ & Sri Lanka ${ }^{1235}$ \\
\hline Austria $^{15}$ & Denmark $^{15}$ & Ireland $^{135}$ & Nicaragua $^{125}$ & Sweden $^{125}$ \\
\hline Belize $^{35}$ & Dominican Rep ${ }^{12345}$ & Israel $^{1245}$ & Niger $^{2}$ & Tajikistan $^{235}$ \\
\hline $\operatorname{Benin}^{1}$ & Ecuador $^{12345}$ & Italy $^{125}$ & Nigeria $^{1235}$ & Tanzania $^{2}$ \\
\hline Bolivia $^{12345}$ & El Salvador ${ }^{12345}$ & Jamaica $^{12345}$ & North Macedonia $^{35}$ & Thailand $^{1245}$ \\
\hline Botswana $^{25}$ & Finland $^{125}$ & Japan $^{15}$ & Norway $^{15}$ & Tunisia $^{15}$ \\
\hline Brazil $^{12345}$ & France $^{15}$ & Kazakhstan $^{125}$ & Panama $^{35}$ & Turkey $^{12345}$ \\
\hline Bulgaria $^{12345}$ & Gambia The ${ }^{235}$ & Korea $\operatorname{Rep}^{1245}$ & Paraguay $^{12345}$ & Ukraine $^{12345}$ \\
\hline Burkina Faso $^{1235}$ & Georgia $^{2}$ & Lao PDR ${ }^{235}$ & Peru $^{12345}$ & United Kingdom $^{15}$ \\
\hline Cabo Verde ${ }^{135}$ & Germany $^{15}$ & Latvia $^{15}$ & Philippines ${ }^{1245}$ & United States ${ }^{15}$ \\
\hline Central African Rep ${ }^{124}$ & Ghana $^{235}$ & Lebanon $^{12345}$ & Portugal $^{1235}$ & Uruguay $^{12345}$ \\
\hline Chile ${ }^{12345}$ & Greece $^{1235}$ & Lesotho $^{25}$ & Romania $^{1245}$ & Venezuela $^{2345}$ \\
\hline China $^{15}$ & Grenada $^{5}$ & Libya $^{25}$ & Russia Fed ${ }^{125}$ & Vietnam $^{135}$ \\
\hline Colombia $^{125}$ & Guatemala $^{2345}$ & Madagascar $^{12345}$ & Senegal $^{12345}$ & Zambia $^{12}$ \\
\hline Comoros $^{35}$ & Guinea-Bissau $^{124}$ & Malawi $^{2345}$ & Sierra Leone ${ }^{1245}$ & \\
\hline Congo Rep ${ }^{125}$ & Guyana $^{125}$ & Mali $^{3}$ & Slovenia $^{15}$ & \\
\hline
\end{tabular}

Notes: 1, 2, 3, 4 and 5 indicate the countries that are, respectively, in the samples of systemic banking, currency, sovereign debt, twin and triple, and all crises. See also Table S1 for crises dates by country and type of crisis. 
T A B L E A 2 Definition of the independent variables and respective sources

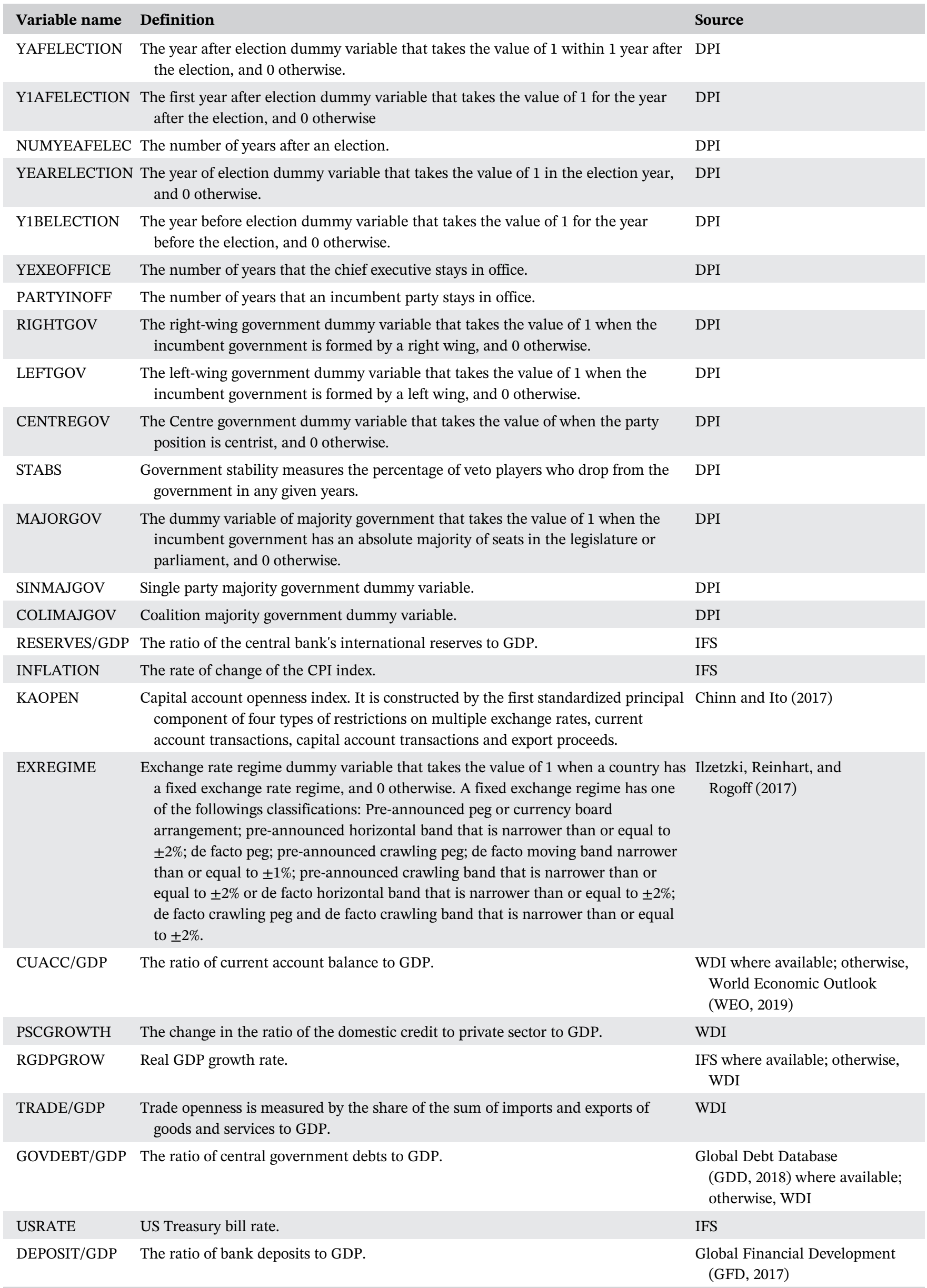




\begin{tabular}{|c|c|c|c|c|c|}
\hline Variable & Observations & Mean & $S D$ & Min & $\operatorname{Max}$ \\
\hline Currency crises & 3,416 & 0.08 & 0.27 & 0 & 1 \\
\hline Banking crises & 3,655 & 0.08 & 0.27 & 0 & 1 \\
\hline Debt crises & 3,438 & 0.28 & 0.45 & 0 & 1 \\
\hline Twin and triple crises & 3,623 & 0.03 & 0.18 & 0 & 1 \\
\hline All crises & 3,469 & 0.35 & 0.48 & 0 & 1 \\
\hline RESERVES/GDP & 3,245 & 13.09 & 17.63 & 0.04 & 302.01 \\
\hline INFLATION & 3,293 & 45.79 & 419.66 & -26.32 & $13,109.5$ \\
\hline KAOPEN & 3,570 & 0.07 & 1.46 & -1.91 & 2.36 \\
\hline EXREGIME & 3,570 & 0.46 & 0.50 & 0 & 1 \\
\hline CUACC/GDP & 3,250 & -3.18 & 8.23 & -65.03 & 62.30 \\
\hline PSCGROWTH & 3,216 & 49.31 & $2,155.41$ & -99.86 & $119,007.9$ \\
\hline RGDPGROW & 3,386 & 3.37 & 5.35 & -62.08 & 123.14 \\
\hline TRADE/GDP & 3,328 & 70.74 & 34.79 & 6.32 & 274.97 \\
\hline GOVDEBT/GDP & 3,282 & 55.67 & 50.25 & 1.19 & 830.27 \\
\hline USRRATE & 3,655 & 0.80 & 2.29 & -3.32 & 5.41 \\
\hline DEPOSIT/GDP & 3,195 & 40.76 & 37.76 & 0.26 & 883.40 \\
\hline YAFELECTION & 3,420 & 0.42 & 0.49 & 0 & 1 \\
\hline Y1AFELECTION & 3,381 & 0.20 & 0.40 & 0 & 1 \\
\hline YEARELECTION & 3,420 & 0.21 & 0.41 & 0 & 1 \\
\hline Y1BELECTION & 3,472 & 0.19 & 0.40 & 0 & 1 \\
\hline NUMYEAFELEC & 3,381 & 2.31 & 2.39 & 0 & 18 \\
\hline YEXEOFFICE & 3,487 & 5.68 & 6.35 & 1 & 45 \\
\hline STABS & 3,334 & 0.14 & 0.29 & 0 & 1 \\
\hline PARTYINOFF & 3,098 & 10.18 & 12.42 & 1 & 71 \\
\hline RIGHTGOV & 2,882 & 0.39 & 0.49 & 0 & 1 \\
\hline LEFTGOV & 2,882 & 0.50 & 0.50 & 0 & 1 \\
\hline CENTREGOV & 2,882 & 0.11 & 0.32 & 0 & 1 \\
\hline MAJORGOV & 3,241 & 0.79 & 0.41 & 0 & 1 \\
\hline SINMAJGOV & 3,215 & 0.53 & 0.50 & 0 & 1 \\
\hline COLIMAJGOV & 3,215 & 0.26 & 0.44 & 0 & 1 \\
\hline
\end{tabular}

TABLE A3 Descriptive statistics

Notes: This table reports the number of observations, mean, $S D$, minimum and maximum values of all variables for the maximum number of countries that can be used in the estimates (85 countries) over the period 1975-2017. 